\title{
Inefficacy of osmotic backwash induced by sodium chloride salt solution in controlling SWRO membrane fouling
}

\author{
A. Mohammed Farooque $\cdot$ Subhi Al-Jeshi $\cdot$ \\ Mohamed O. Saeed · Ali Alreweli
}

Received: 30 July 2013/Accepted: 10 February 2014/Published online: 6 March 2014

(c) The Author(s) 2014. This article is published with open access at Springerlink.com

\begin{abstract}
A study was conducted to evaluate the efficacy of osmotic backwash induced by high salt $(\mathrm{NaCl})$ concentration solution on feed side of seawater reverse osmosis (SWRO) membranes, online and offline, in controlling membrane fouling and therefore minimizing/ eliminating the need for chemical cleaning. SWRO membranes were deliberately fouled by feeding seawater from an open intake located on the Arabian Gulf Coast without dosing chemicals. The fouled membranes were subjected to offline cleaning with the salt solution of up to $25 \%$ concentration. Despite the partial removal of foulants from the membrane surface, SWRO membrane performance could not be restored, indicating the ineffectiveness of osmotic backwash in aiding offline salt cleaning. Similarly, online osmotic backwash was found to be not only ineffective in removing foulants from membrane surfaces but actually increased the fouling rate, as indicated by faster fouling rates compared to other cases. Although the driving force required for the osmotic backwash existed, the generated back flow proved to be insufficient to detach foulants from membrane surfaces. During the study period, the average SWRO membrane flux was maintained between 19 and 23 $\mathrm{LMH}$, whereas the average generated back flow flux by high salt concentration solution was only $11 \mathrm{LMH}$, which was not adequate to remove foulants from membrane surfaces. Moreover, it seems that the membrane configuration as well as inherent microstructure of SWRO membrane
\end{abstract}

A. M. Farooque $(\bowtie) \cdot$ M. O. Saeed · A. Alreweli SWCC SWDRI, P.O. Box 8328, Jubail 31951, Saudi Arabia e-mail: amfarooque@swcc.gov.sa

S. Al-Jeshi

Midra Tower, Saudi Aramco, Box 18052, Dhahran 31311, Saudi Arabia places certain constraints on the osmotic backwash process and renders osmotic backwash ineffective in tackling SWRO membrane fouling. Hence, chemical cleaning is essential to restore SWRO membrane performance whenever fouling occurs, and the use of highly concentrated salt solution does not have any significant benefit. Membrane autopsy revealed only an insignificant accumulation of biofouling layer despite the absence of disinfection. However, it was shown that culturable biofilm bacteria species isolated from membranes tolerated exposure to high salt concentrations at $\mathrm{pH}$ range of 7-8. In addition, the overall findings of the study indicate that SWRO membranes can be operated in Gulf seawater at a recovery of $30 \%$ without using any chemicals, such as coagulant, disinfectant and antiscalant, for an acceptable period of time without performing membrane cleaning. This is highly likely, if media filters are used in the pretreatment and SWRO membranes are operated at normal flux and recovery ratio.

Keywords SWRO membrane $\cdot$ Fouling Cleaning · Osmotic backwash $\cdot$ Salt cleaning

\section{Introduction}

Fouling is a complex phenomenon that is difficult to define and a major problem faced by desalination industries employing membrane separation processes. Generally fouling is the undesirable deposition or accumulation of solids on the membrane surface. Fouling inhibits flow through the membrane resulting in an eventual decline in overall flux, poor permeate quality, higher pressure demand (higher energy), additional labor for maintenance and chemicals for cleaning, production loss and shorter 
membrane life. Usually, reverse osmosis (RO) membrane desalination industries employ two different strategies to combat fouling. The first one is prevention, which is accomplished by supplying high-quality feed water to the membranes. However, conventional pretreatment (coagulation/filtration) or even the advanced membrane (MF/UF) pretreatment processes which are used to attain the desired level of feed water quality are not capable of preventing fouling completely. The second strategy is to clean the membrane chemically to remove foulants from the membrane surface. SWRO membrane desalination industries mainly use chemicals, such as alkalis, acids, metal chelating agents, enzymes and detergents, which are expensive and potentially harmful to the environment. Hence, RO desalination industries need an alternative environmentally friendly and cost-effective method to control fouling/ scaling.

Recently, a high concentration of common salt $(\mathrm{NaCl})$ has been successfully used to prevent fouling (Liberman and Liberman 2005; Liberman et al. 2007; Qin et al. 2009, 2010) as well as clean fouled RO membranes (Lee and Elimelech 2007). Common table salt is not only very cheap but it is readily soluble in water and it forms the major component of seawater itself. Hence, the application of a high concentration of sodium chloride $(\mathrm{NaCl})$ and the resulting osmotic backwash phenomenon do have great significance in desalination. An increase in salt concentration to a very high value on the feed side of a RO membrane results in high osmotic pressure, which leads to natural osmotic backwash from the permeate side to the feed-brine side (Ramon et al. 2010). This process enables the dislodging of foulants and scales adhering feed-brine surface of the membrane. Moreover, a high concentration of salt could be detrimental to the biofouling community and hence prevent biofouling.

In one study, several different inorganic salts were used to clean artificially fouled $\mathrm{RO}$ membranes and proved that $\mathrm{NaCl}$ salt solution can efficiently clean fouled RO membranes (Lee and Elimelech 2007). Although this study was carried out on a bench-scale set up with artificial organic foulants, the results indicate that a high concentration of salt can be used in offline mode to clean RO membranes. On the other hand, regular online osmotic backwash can be applied to RO membranes in operation by dosing high concentration of salt in order to prevent foulant build-up on the membrane surface. This was, reportedly, implemented successfully in two commercial brackish water reverse osmosis (BWRO) plants (Liberman and Liberman 2005) as well as on commercial SWRO membranes (Liberman et al. 2007). Moreover, a systematic study was carried out by assessing the efficiency of online osmotic backwash of RO membranes treating secondary effluent water (Qin et al. 2010). There have been very few studies on the efficiency of osmotic backwashing (Sagiv and Semiat 2005; Sagiv et al. 2008; Avraham et al. 2006), especially for SWRO membranes and there are no detailed studies available. Moreover, there are currently very few data from which the effectiveness of an osmotic-induced backwash may be deduced. Hence, the present study used both approaches (offline and online) and evaluated the efficiency of the two methods in preventing/controlling fouling, and eliminating or decreasing the cleaning frequency of SWRO membranes. If these approaches prove to be successful, membrane desalination plant should benefit from such an environmentally friendly and cost-effective method of both preventing RO membrane fouling and cleaning fouled membranes.

\section{Experimental}

Pilot plant description

Experiments were carried out using an SWRO pilot plant. The plant consisted of a sand media filtration unit, SWRO membrane unit and chemical dosing system. A schematic diagram of the pilot plant is shown in Fig. 1. The highpressure pump of the SWRO membrane unit is capable of delivering $1 \mathrm{~m}^{3} / \mathrm{h}$ of feed flow with maximum discharge pressure of 70 bar. The SWRO membrane unit consists of two pressure vessels arranged in series, and each pressure vessel carries a single spiral wound SWRO membrane of 4 in. $\times 40$ in. size. Commercial thin film composite spiral wound SWRO membranes were used throughout the experiment. However, later on during the course of the study, the pilot plant was modified by removing the media filter and eventually the acid dosing system in order to

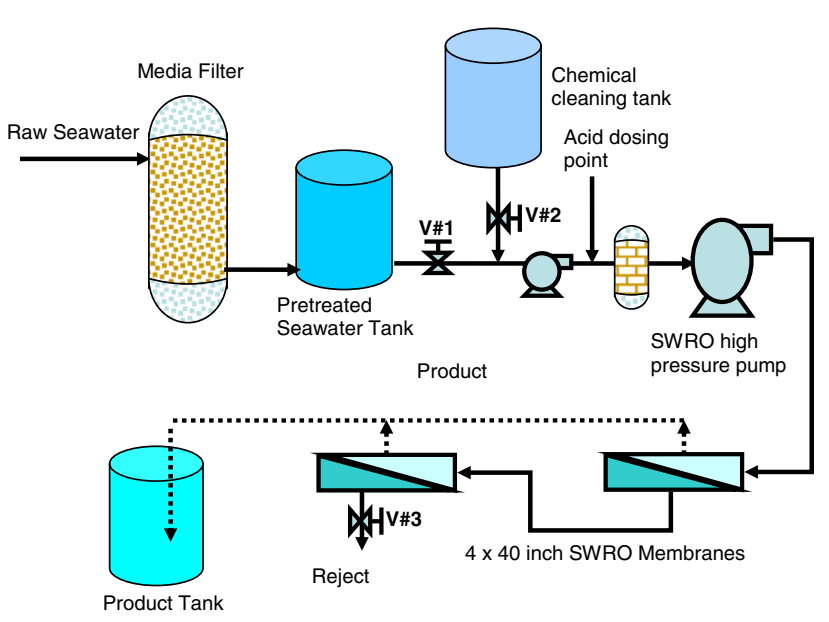

Fig. 1 Schematic flow diagram of the modified SWRO pilot plant used in the initial stage 


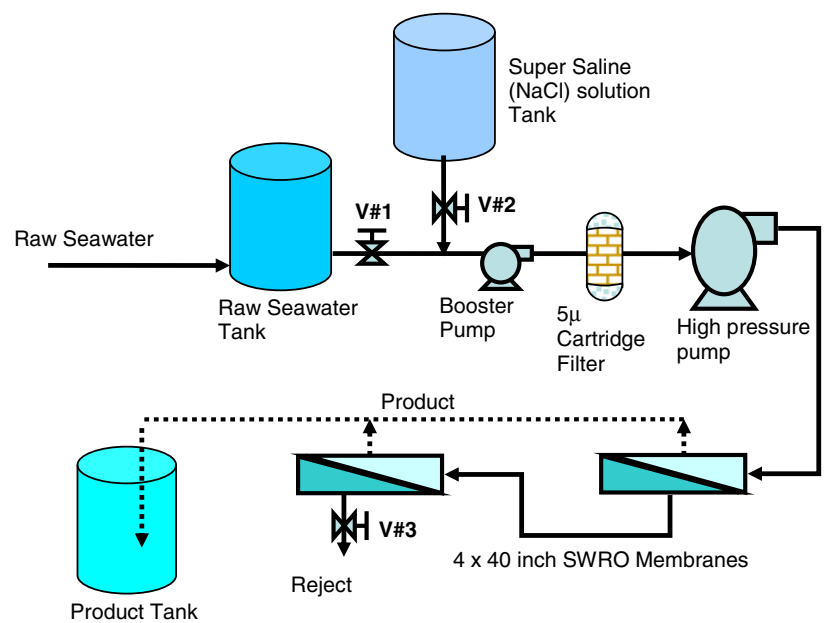

Fig. 2 Schematic flow diagram of the modified SWRO pilot plant used in the final stage

accelerate membrane fouling. A schematic diagram of the pilot plant in this form is shown in Fig. 2. Commercial grade $\mathrm{NaCl}$ was used to prepare a high salt concentration, and the operation of the pilot plant was controlled manually.

\section{Pilot plant trials}

The feed water was obtained from an open intake located on the Arabian Gulf Sea and fed to the SWRO membrane after passing through a sand filter without adding any chemicals except sulfuric acid (to control scaling by maintaining $\mathrm{pH}$ at about 7 during early stages). No coagulant or disinfectant was added. A single cartridge filter with nominal pore size of $5 \mu$ was used (Fig. 1). This arrangement was adopted to accelerate membrane fouling and the SWRO membrane unit was initially operated at a feed flow rate of $1 \mathrm{~m}^{3} / \mathrm{h}$ and at a recovery of $25 \%$ corresponding to a membrane water flux of $19.2 \mathrm{l} / \mathrm{m}^{2} / \mathrm{h}(\mathrm{LMH})$. However, after (initially) operating for about a month, the operation conditions were changed due to the very slow fouling rate on the membranes. Hence, for the remaining period, the sand filter was bypassed and recovery was raised to $30 \%$, resulting in an increased membrane flux with an extremely high value of $23 \mathrm{LMH}$ (Fig. 2). In addition, the feed $\mathrm{pH}$ was gradually raised by reducing acid dosing and subsequently by completely stopping the acid injection so that ambient seawater $(\mathrm{pH} \approx 8)$ was used. Plant operation data, such as flow, temperature, $\mathrm{pH}$, conductivity and the pressure of SWRO feed, product and reject were collected on a daily basis. Performance decline due to fouling was estimated based on the reduction in normalized flow and salt rejection. Normalization was carried out according to standard ASTM procedure (451685 1989).

\section{Baseline study}

At the beginning of the study, a new set of SWRO membranes was evaluated in order to assess the membrane fouling potential during normal operation. Baseline data at a feed water $\mathrm{pH}$ of about 7 were established, where several chemical cleanings were performed using a standard cleaning procedure whenever the normalized flow declined by about $10-15 \%$. The standard chemical cleaning procedure involved a first cleaning with a low $\mathrm{pH}(\approx 4)$ solution of $2 \%$ citric acid, followed by high $\mathrm{pH}(\approx 11)$ cleaning using $0.025 \%$ sodium lauryl sulfate (SDS). The cleaning was performed at a flow rate of $2 \mathrm{~m}^{3} / \mathrm{h}$ and at a pressure of $<4$ bar, with a $1 \mathrm{~h}$ recirculation, $1 \mathrm{~h}$ soaking and $1 \mathrm{~h}$ recirculation mode at ambient temperature. The trial was ended after obtaining sufficient data on membrane fouling. Later on, towards the end of the study, the baseline study was repeated twice, at a feed water $\mathrm{pH} \approx 8$ with new sets of membranes without dosing sulfuric acid.

\section{Offline salt cleaning}

Following the initial baseline study, a trial was performed on a new set of membranes where offline cleaning was applied with a salt concentration in the range of 22-25\%, when the normalized performance declined by $10-15 \%$. The operation conditions for offline salt cleaning were the same as those used in the chemical cleaning procedure in the baseline study.

\section{Online salt cleaning}

During the initial stages of online salt cleaning, a concentration of about $10 \%$ was dosed for 1 min daily (while the SWRO unit was in operation) by opening and closing the feed valve (V\#1) and cleaning tank valve (V\#2) simultaneously as shown in Fig. 2. However, this mode of operation led to an increase in feed pressure. Hence, later on, the experiment was repeated with a new set of membranes where the feed pressure was maintained constant by controlling the brine valve (V\#3) as shown in Fig. 2. Towards the end of the trial, a higher concentration of salt (up to $24 \%$ ) was used with daily dosing for a period of $2 \mathrm{~min}$. This experiment was also repeated with a new set of membranes as there was a sudden unexpected increase in permeate conductivity during the second trial.

\section{Bacteriological studies}

Regular bacteriological analyses were carried out on water samples obtained from the seawater feed to membranes, from feed after the $5 \mu$ cartridge filter (AMCF), and from brine reject. Water samples were collected in sterile plastic 
sampling bags. The bacteria were counted immediately and again after $24 \mathrm{~h}$ incubation of the samples at a temperature of $30{ }^{\circ} \mathrm{C}$ in a thermostatically controlled microbial incubator. The samples were first mixed thoroughly on a vortex mixer, and a pour plate count in marine agar (Difco 2216) was employed to reveal the colony-forming units (CFU).

\section{Autopsy studies}

Following the completion of each task, autopsy was performed on all used membranes to determine the type and extent of fouling on each membrane. The autopsy procedure included dissection of membranes, estimation of surface foulant depositions and chemical analyses. Chemical analyses, mainly involving quantitative identification of inorganic constituents, were carried out on the foulant scraped off the membrane surface after thorough drying of the samples. Inorganic elemental analyses were carried out using the Hitachi Model 306 Super Scan ICP Emission Analysis System for the foulants removed from the first trial of baseline study, whereas foulants from the rest of membranes were analyzed by X-ray fluorescence (XRF) technique using JEOL JSX-3400II energy dispersive an $\mathrm{X}$-ray fluorescence spectrometer. Loss of ignition of dried foulant at $550{ }^{\circ} \mathrm{C}$ was used as a rough estimate of total primary organic matter content in the foulant deposit. In addition, samples were excised from different parts of membranes and dried thoroughly before analyzing the deposits on membrane surfaces using a scanning electron microscope (SEM) JEOL JSM 6480LV and an energy dispersive X-ray (EDX) spectrometer, Oxford Inca Energy 250. Biofilm bacteria were estimated on some of the autopsied membranes after removing excised pieces of membrane sheets. Cut pieces of membrane were washed in two changes of sterile (filtered and autoclaved) aged seawater with moderate shaking to remove unattached bacteria. Following the washing and decanting of the washed solution, biofilms on the cut pieces of membrane were aseptically scraped off in $10 \mathrm{ml}$ of sterile seawater in standard-size Petri dishes using sterile scalpel. Following appropriate dilutions, samples were seeded in marine agar to reveal the number of colony-forming units (CFU). CFU were back calculated to reveal the density of biofilm on the membrane in $\mathrm{CFU} / \mathrm{cm}^{2}$ of the membrane.

\section{Results and discussion}

\section{Baseline studies}

During the baseline study, two new SWRO membranes were initially (first trial) operated in series at a feed flow rate of $1 \mathrm{~m}^{3} / \mathrm{h}$ and at a product recovery of $25 \%$. The feed to the membrane was raw seawater (taken from an open intake) which was passed through a single stage sand media filter followed by a cartridge filter of $5 \mu$ pore size with only the addition of sulfuric acid to maintain the $\mathrm{pH}$ at about 7 (see Fig. 1). The SDI of seawater feed to the membrane was between 3 and 5. Under these operating conditions, the average flux of the membrane was 19.2 $\mathrm{LMH}$, which was much higher than the normal flux $(<15$ LMH) adapted for membranes receiving seawater feed from an open intake. In addition, the single-membrane element water recovery exceeded $10 \%$, which is the maximum recommended value in normal cases. These stringent conditions were used to accelerate the fouling on membranes and to gather sufficient baseline data on the chemical cleaning of the membrane with respect to performance restoration. The operation conditions were changed after 30 days as there was no substantial fouling observed, as indicated by a very slow decline in normalized flow (see Fig. 3). In practice, a 10-15\% decline in the normalized flow or normalized differential pressure or normalized salt rejection are the accepted criteria for cleaning membranes to restore membrane performance. However, none of these values reached the targets even after 30 days characterized by a very slow fouling rate. As a result, the sand filter was bypassed while recovery increased to $30 \%$, resulting in an increase of the average membrane flux to $23 \mathrm{LMH}$, subsequently resulted in relatively faster fouling as indicated by the approximate $10 \%$ decline in normalized flow. Following that change in operating conditions, a total of five chemical cleanings were carried out using a standard cleaning solution. Although initial chemical cleanings were partially successful in restoring membrane performance, subsequent cleanings were found to be ineffective, a possible indication of irreversible membrane fouling. Once sufficient data were accumulated over a total operation period of 97 days, the first trial was completed and membranes were removed for autopsy.

Towards the end (second trial) the baseline study was repeated without dosing sulfuric acid (feed $\mathrm{pH} \approx 8$ ) in order to prove that the absence of acid or antiscalant does not lead to scaling on the membrane surface. This was required especially because during the offline (most of the time) and online salt cleaning phase of the experiment, sulfuric acid was not dosed during normal operation. However, the performance decline in this case did not differ much from that in the first trial. The feed pressure slowly increased to the maximum at a relatively constant feed temperature indicating fouling. Once the maximum feed pressure was reached, membranes were removed for autopsy analyses. During this period of 41 days operation, no chemical cleaning was conducted. The experiment was again repeated (third trial) with new sets of membrane until 
Fig. 3 Performance parameters of SWRO membranes during baseline study. a Operation conditions, b permeate flow and c permeate conductivity

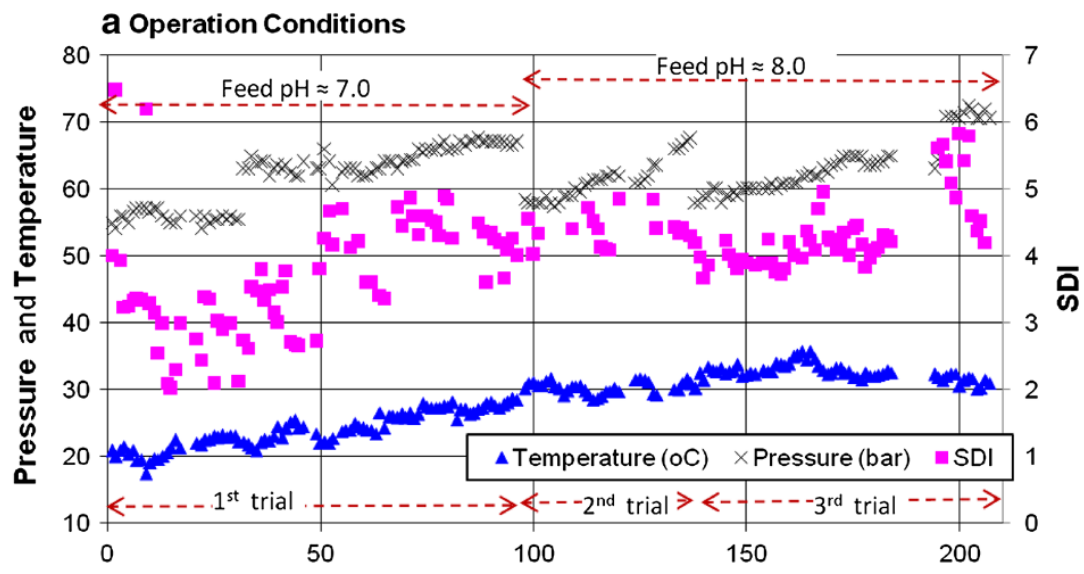

b Permeate Flow Rate
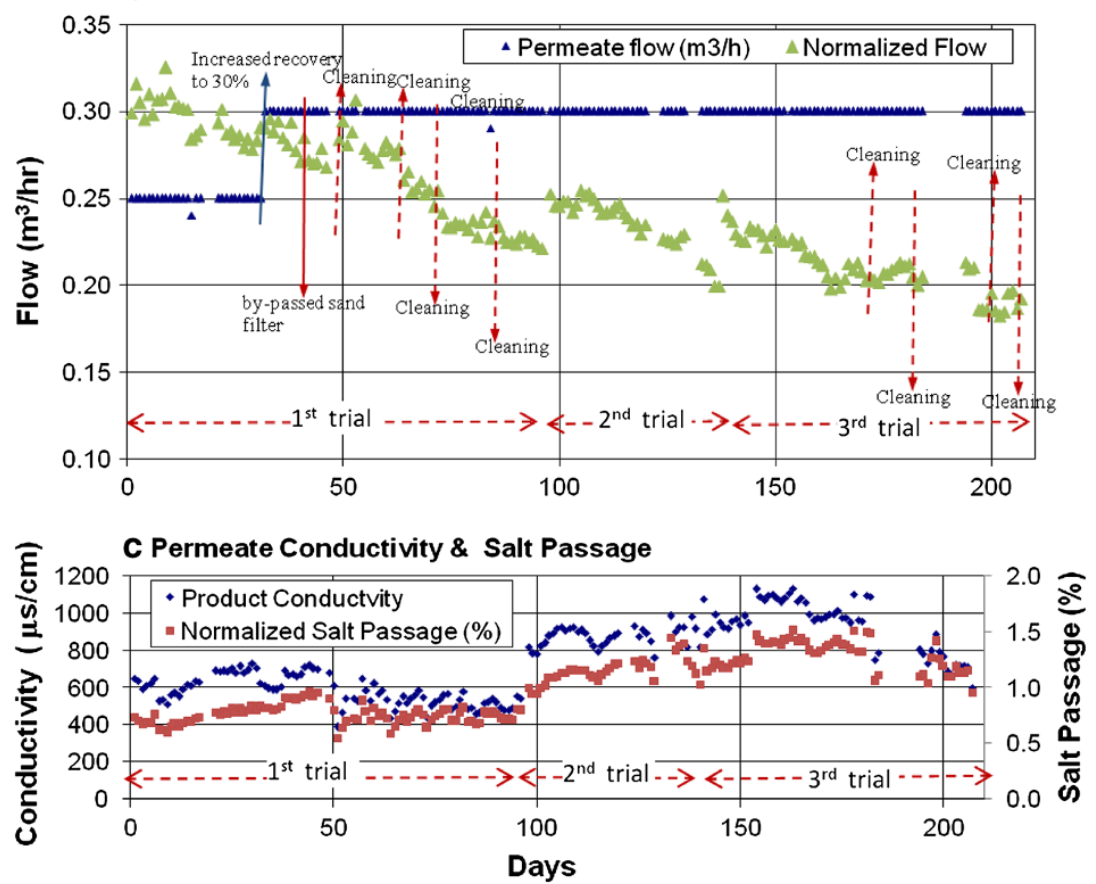

the normalized flux decreased by about $15 \%$. After that, a total of four chemical cleanings were conducted, which did not affect the performance of the membrane thus indicating that the fouling was irreversible in nature and that the chemical cleaning (performed) were incapable of restoring membrane performance (see Fig. 4). Finally, these membranes were in operation for a period of 70 days. Moreover, they were removed from pressure vessels for autopsy after $1 \mathrm{~h}$ of operation following the final chemical cleaning.

\section{Offline salt cleaning}

Membrane cleaning using a high concentration of salt solution was carried out following the baseline study (first trial). The operating conditions were the same as those used in the baseline study, and the schematic diagram of the system used in its final form is shown in Fig. 2. During this study, offline salt cleaning was carried out using a salt solution with a concentration $>20 \%$. However, it was observed that the conditions set for the faster fouling did not actually accelerate fouling, i.e., even after waiting for 1 month no significant decline in performance was observed that warrant a cleaning. The membranes are to be fouled fast so as to perform a sufficient number of cleanings in a limited period to confirm the findings, hence the need for accelerated fouling of the membrane. However, a further increase in flux was not possible due to feed pressure limits of the membrane. As a result, it was decided to gradually increase the $\mathrm{pH}$ of the feed seawater to achieve faster fouling/scaling of the membrane. Thus, feed $\mathrm{pH}$ to the membrane increased gradually from 7.0 to 8 (no acid operation). Consequently, a total of three membrane cleanings were conducted using super saline solution as there was a slight decline of $<10 \%$ in the normalized flow. 
Fig. 4 Performance parameters of SWRO membranes during offline salt cleaning. a Operation conditions, b permeate flow and $\mathbf{c}$ permeate conductivity
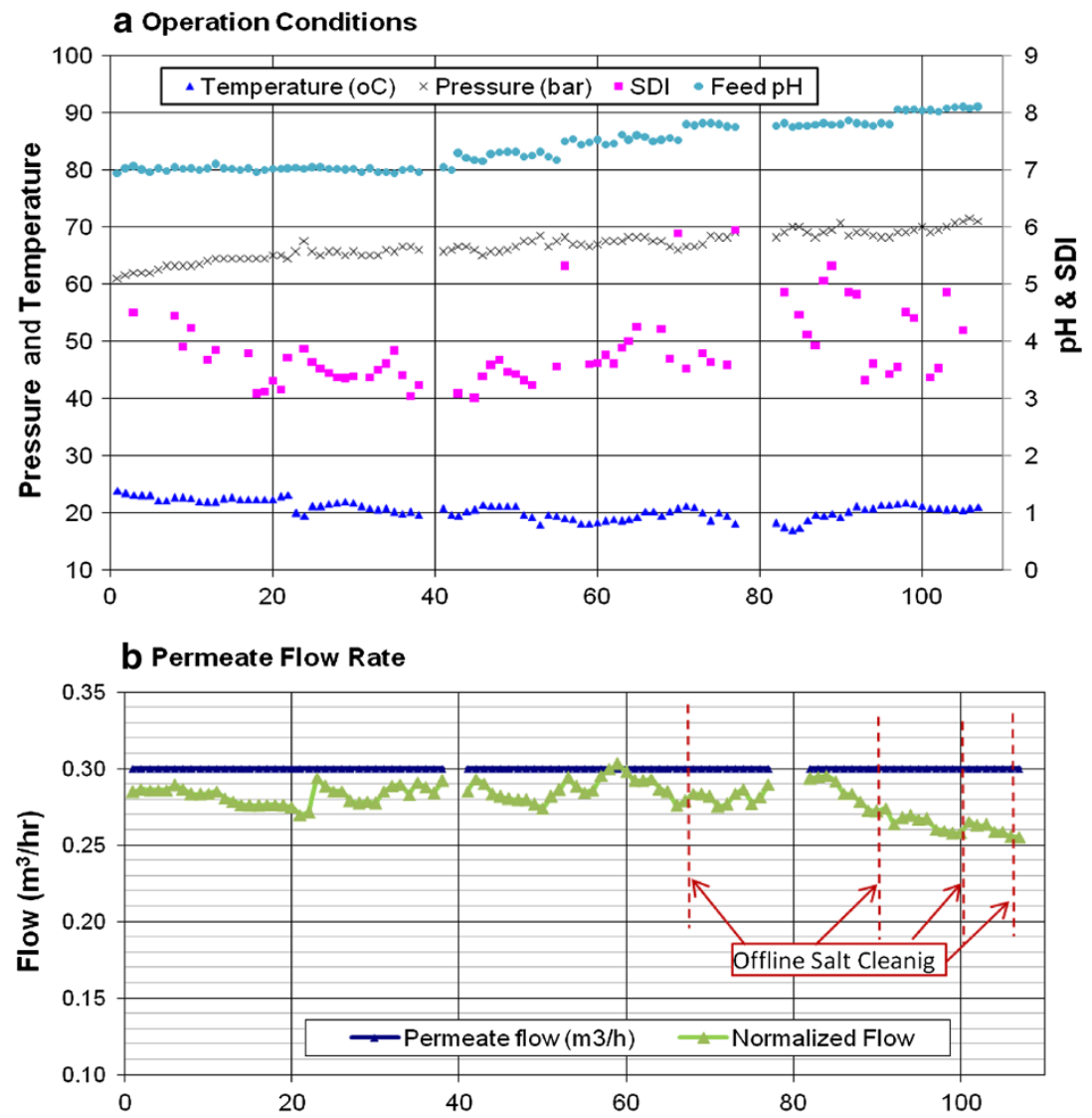

C Permeate Conductivity \& Salt Passage

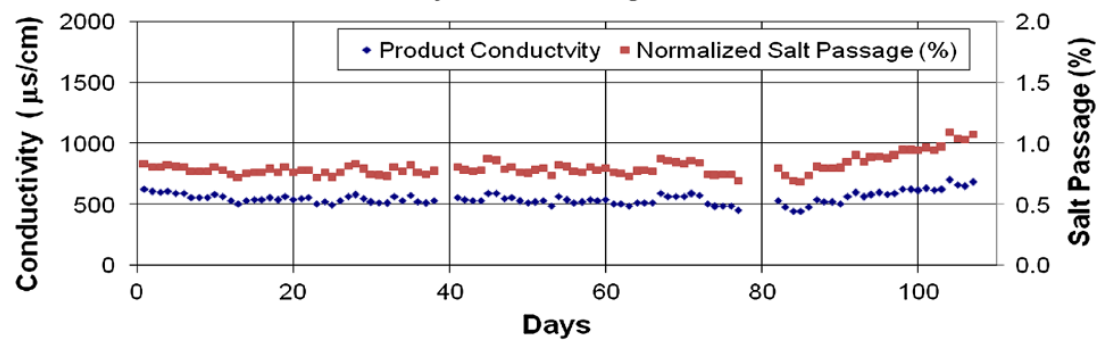

Although during salt cleaning significant amount of foulants was removed from the membrane surface (as evident from the strong discoloration of the cleaning solution exiting from brine side), no noticeable recovery of the lost membrane performance was achieved (Fig. 4). These foulants could have been loosely bound to the membrane surface, and thus easily removed by the forward flushing action of cleaning solution due to feed cross-flow velocity, which is quite normal. However, the osmotic backwash action seemed to have little impact on removing foulant from membrane surfaces. Thus, the results indicate that the offline salt cleaning, even with a very high concentration of salt solution, did not help the recovery of membrane performance. This result is quite different from that obtained when salt was used to clean artificially fouled RO membranes in a bench-scale test unit, where it was effective in restoring membrane performance (Lee and Elimelech 2007). The nature of the foulant as well as membrane configuration and microstructure might have played a role in rendering the salt cleaning ineffective in the present study. Once sufficient data were collected, the membranes were removed and subjected to autopsy analyses.

\section{Online salt cleaning}

Following the completion of the offline salt cleaning trial, online dosing of salt was carried out on a new set of SWRO membranes. A total of three trials were conducted during this phase. Initially (first trial), the online salt cleaning was conducted with a salt concentration of about $10 \%$ and a dosing time of 1 min on a daily basis, which was later increased to $2 \mathrm{~min}$ as it was not found to be 
Fig. 5 Performance parameters of SWRO membranes during online salt cleaning. a Operation conditions, $\mathbf{b}$ permeate flow and c permeate conductivity
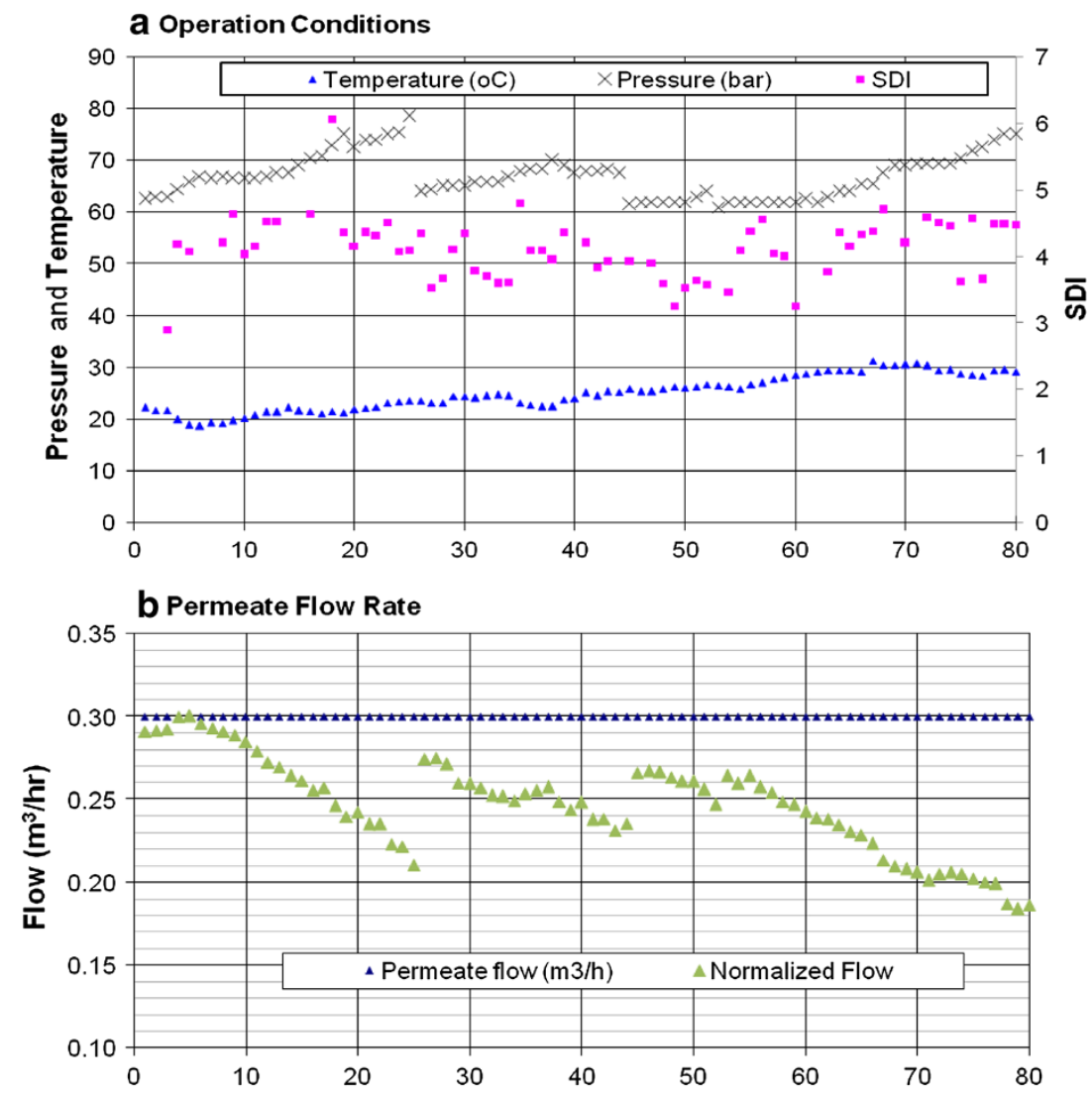

C Permeate Conductivity \& Salt Passage

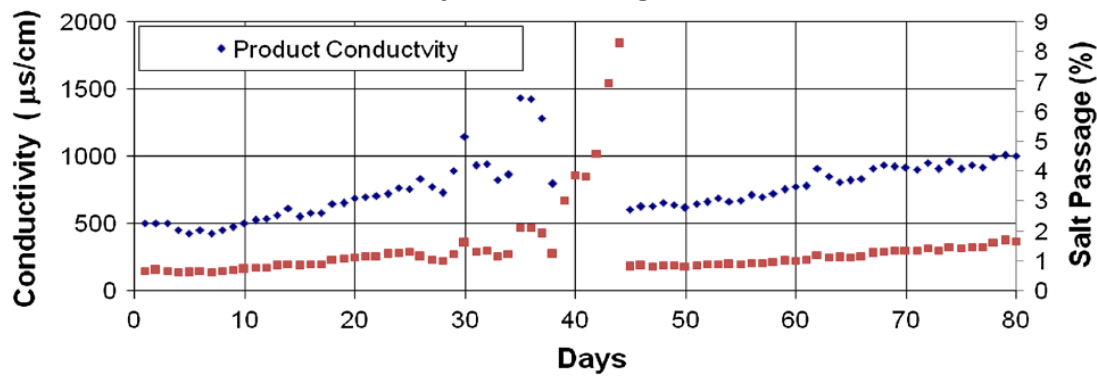

effective in arresting performance decline. Dosing salt solution for 1 min consumes about 16.71 of salt solution which is more than sufficient to fill the two empty pressure vessels (where the maximum volume per vessel is only 8.251 ). Hence, it was assumed that 1 min dosing is more than sufficient to produce an effective osmotic backwash action on both membranes due to the large osmotic pressure difference between the permeate and feed solution. During the salt solution dosing, it was observed that the feed pressure increased to a higher level for a short period of time before returning to the original one. This phenomenon is mainly due to the throttling effect which occurs while dosing super saline solution during which no permeation takes place through the SWRO membrane. This results in increase of flow through feed-brine channel and consequently increases the feed pressure. Moreover, due to osmotic backwash, the permeate enters feed channel due to the osmotic pressure difference between the feed and permeate. The increase in feed pressure was found to be proportional to the concentration of super saline solution as a higher concentration resulted in a greater increase in feed pressure which went up to 100 bar when a $13 \%$ salt solution was used. Although this mode of operation lasted about 25 days, no membrane damage occurred, as evident from the performance as well as autopsy results. The membranes were removed for autopsy once the feed pressure exceeded $70 \mathrm{bar}$, which is the maximum pressure the membrane can withstand. During this period, the performance of the membrane rapidly declined in terms of normalized flow (a decline of $28 \%$ towards the end), indicating rapid fouling along with possible membrane 
compaction (see Fig. 5). Hence, a new set of membranes was brought into service after removing the membranes for autopsy analyses.

During the second trial, the feed pressure to the membranes was maintained constant by controlling the brine valve, initially by opening and subsequently by closing towards the end of the salt dosing, so that no increase in feed pressure occurred, as witnessed in the first trial. Also, the salt concentration was increased to about 22-24\%. However, after about 2 weeks of operation, a rapid increase in salt passage was observed which made it necessary to replace the membranes with a new set. During this period, a decline in the normalized flow (by about $14 \%$ ) was observed (Fig. 5). Thus, a new set of membranes was installed and operated for 36 days (third trial), which also showed a rapid decline in performance, both in terms of normalized flow (by about $30 \%$ ) and salt passage. However, compared to the first set of membranes, the decline rate in this case was slightly lower (22\% during a 36-day period compared to $28 \%$ during the uncontrolled feed pressure phase of 25 days, i.e., first trial). This could have been due to the absence of compaction which was less in this case as there was no pressure build-up as in the case of first trial. In short, all three trials using online salt dosing accelerated rather than prevent fouling, as can be seen from the rapid performance decline compared to the baseline performance. Strangely, these results differ from those obtained in other studies, where it was reported that osmotic backwash induced by online salt dosing was effective in controlling membrane fouling (Liberman and Liberman 2005; Liberman et al. 2007; Qin et al. 2010).

\section{Bacteriological studies}

Bacterial counts were steady with no abnormal values at any of the sampling sites during all phases of the study and during all four seasons; indicating that changing operation parameters had no effect on bacterial densities. At $0 \mathrm{~h}$, bacterial density was, in the vast majority of samples, at two orders of magnitude $\left(\times 10^{2} \mathrm{CFU} / \mathrm{ml}\right)$, and rarely at three orders of magnitude $\left(\times 10^{3} \mathrm{CFU} / \mathrm{ml}\right)$. After $24 \mathrm{~h}$ incubation, the after growth was mostly at five orders of magnitude $\left(\times 10^{5} \mathrm{CFU} / \mathrm{ml}\right)$ and rarely at four orders of magnitude. Both 0 and $24 \mathrm{~h}$ bacterial densities were normal values for Gulf coastal seawater at Jubail desalination and power plants. They indicate normal source water, which is free of any added material such as chlorine and nutrients (Saeed 2002).

$0 \mathrm{~h}$ bacterial density at $\mathrm{AMCF}$ was stable at $\times 10^{3} \mathrm{CFU} /$ $\mathrm{ml}$ and the same was true for brine reject. Density at $\mathrm{AMCF}$ and brine reject was higher by one order of magnitude than that observed in feed water. This difference is negligible and arises from bacterial sloughing from biofilms on the cartridge filter $(\mathrm{CF})$ and membranes, respectively. The observed density does not reflect significant fouling on either the CF or membranes. The 24-h count for $\mathrm{AMCF}$ and brine reject was stable at $\times 10^{5}$, similar to that in feed water. Although the biofouling potential of feed water was significant, counts at AMCF and in the brine reject did not reflect significant membrane fouling (Saeed 2000).

\section{Autopsy studies}

\section{Physical and chemical analyses}

Autopsies were conducted on all 14 membranes used in this study. Autopsy of membranes removed after the first baseline study (first trial) showed that both the lead and the end elements were covered with loosely bound deposits, as shown in the Fig. 6. The dry weight of foulants on the membrane surface was 0.066 and $0.042 \mathrm{mg} / \mathrm{cm}^{2}$ in the lead and end elements. Membranes were in operation at a feed $\mathrm{pH}$ of 7 for about 97 days and were subjected to 5 chemical cleanings. Autopsy was performed 12 days after the last chemical cleaning. Detailed chemical analyses (Table 1) of the deposits revealed that it mainly consisted of silt and primary organic matter with some iron, which was further

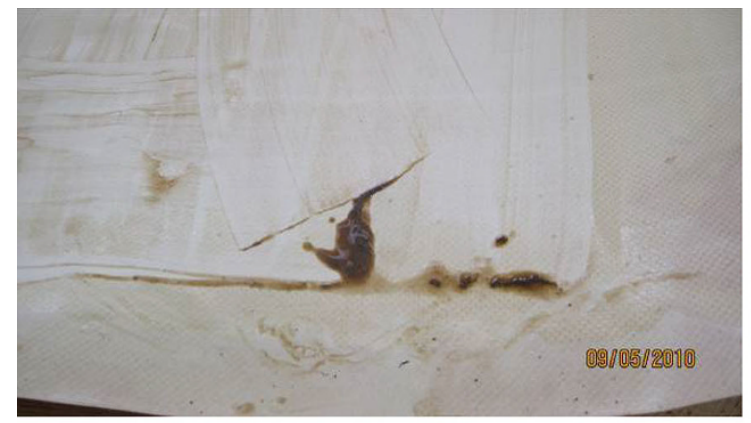

Lead Element

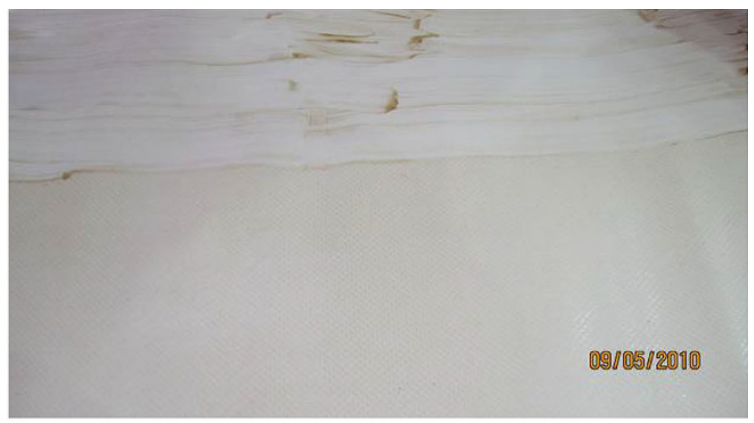

End Element

Fig. 6 Photographs of membrane elements used in baseline study—first trial—showing foulant deposits and scraped area 
Table 1 Analyses of foulant deposits on the autopsied membranes used in baseline study

\begin{tabular}{|c|c|c|c|c|c|c|}
\hline \multirow{2}{*}{$\begin{array}{l}\text { Membrane } \\
\text { element }\end{array}$} & \multicolumn{2}{|l|}{ 1st trial } & \multicolumn{2}{|l|}{ 2nd trial } & \multicolumn{2}{|l|}{ 3rd trial } \\
\hline & $\begin{array}{l}\text { Lead } \\
\text { element }\end{array}$ & $\begin{array}{l}\text { End } \\
\text { element }\end{array}$ & $\begin{array}{l}\text { Lead } \\
\text { element }\end{array}$ & $\begin{array}{l}\text { End } \\
\text { element }\end{array}$ & $\begin{array}{l}\text { Lead } \\
\text { element }\end{array}$ & $\begin{array}{l}\text { End } \\
\text { element }\end{array}$ \\
\hline $\begin{array}{l}\text { Foulant } \\
\qquad\left(\mathrm{mg} / \mathrm{cm}^{2}\right)\end{array}$ & 0.066 & 0.042 & 0.059 & 0.033 & 0.027 & 0.005 \\
\hline $\begin{array}{l}\text { Primary } \\
\text { organic } \\
\text { matter } \\
(\%)\end{array}$ & 59.20 & 48.20 & NA & & & \\
\hline $\mathrm{Na}(\%)$ & 0.60 & 0.60 & & & & \\
\hline $\operatorname{Mg}(\%)$ & 0.90 & 1.00 & & & & \\
\hline $\mathrm{Al}(\%)$ & 1.20 & 0.80 & & & & \\
\hline K (\%) & 0.80 & 0.60 & & & & \\
\hline $\mathrm{Ca}(\%)$ & 1.10 & 0.60 & & & & \\
\hline $\mathrm{Fe}(\%)$ & 4.10 & 2.20 & & & & \\
\hline
\end{tabular}

confirmed by SEM and EDX analyses (Fig. 7). Although primary organic matter constituted about $50 \%$ of the foulant deposit, there no severe biofouling on the membrane as evident from clean feed spacers and a lack of foul odor, despite the SWRO unit being operated without the
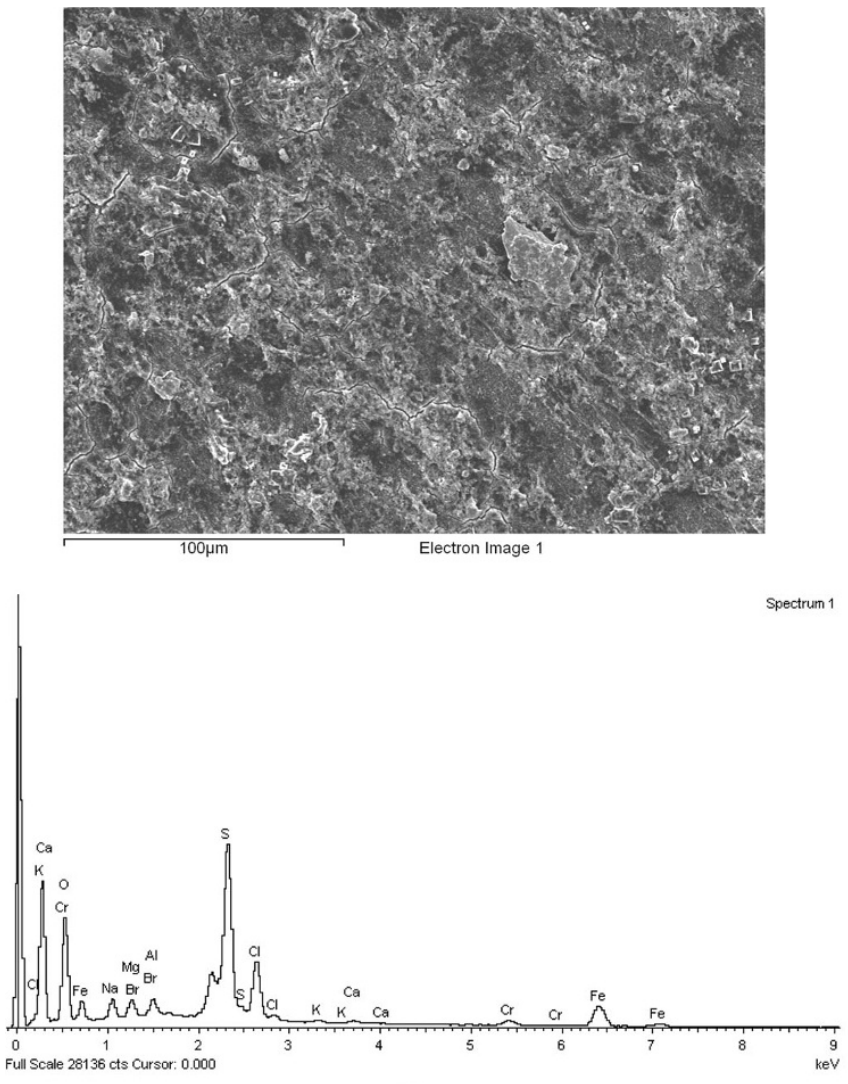

Lead Element application of any disinfectant. Membranes from second baseline study (second trial) were operated at a feed $\mathrm{pH}$ of 8 for about 41 days without any chemical cleaning and showed similar foulant deposits to those in the first trial (Fig. 8). Also, the amount of dry foulants on the membrane was similar to that of the first trial, i.e., 0.059 and $0.033 \mathrm{mg} / \mathrm{cm}^{2}$ in the lead and end elements, respectively. Also, the SEM and EDX results were similar (Fig. 9) to those found in first trial. These results indicate that SWRO membranes can be operated for a substantial period of time at $30 \%$ recovery without dosing any antiscalant. During the third baseline study (third trial), the membranes were operated for a period of 70 days at a feed $\mathrm{pH}$ of 8 and a total of three chemical cleanings were carried out. Membranes were removed immediately after the final chemical cleaning in order to observe the effect of chemical cleaning on removing foulant deposits from the membrane surface. Although on examination both membranes appeared relatively clean with very little deposit on the lead element (Fig. 10), the foulant estimation (Table 1) as well as SEM and EDX analyses (Fig. 11) showed the presence of very small amounts of foulant despite chemical cleaning. These deposits could have accumulated during the short period $(1 \mathrm{~h})$ of operation, or could be foulant remaining on the
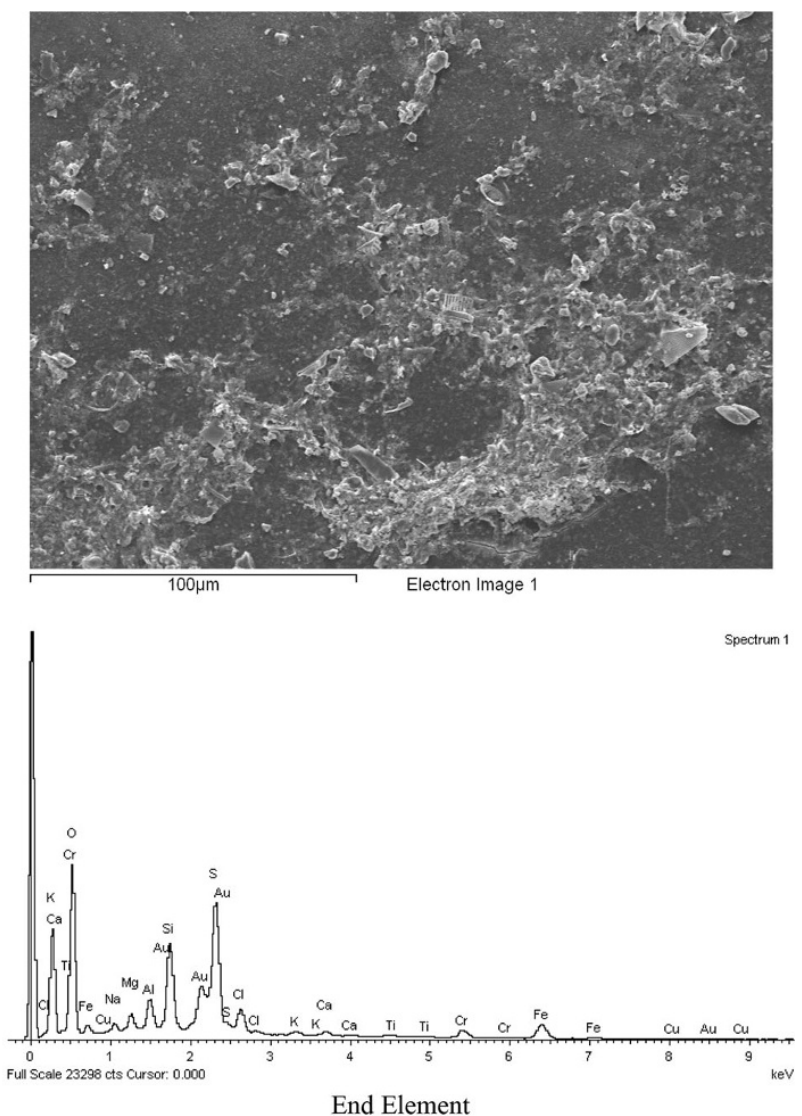

End Element

Fig. 7 SEM image and corresponding EDX spectrum of membrane elements used in baseline study—first trial—showing foulant deposits 


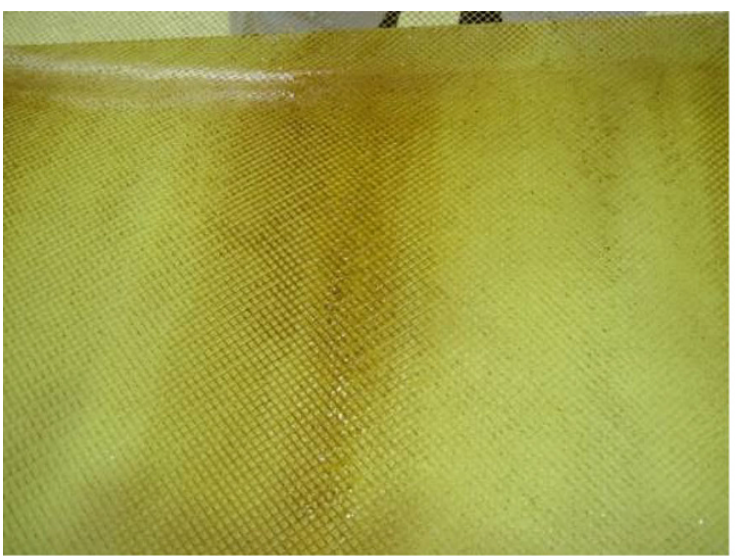

Lead Element

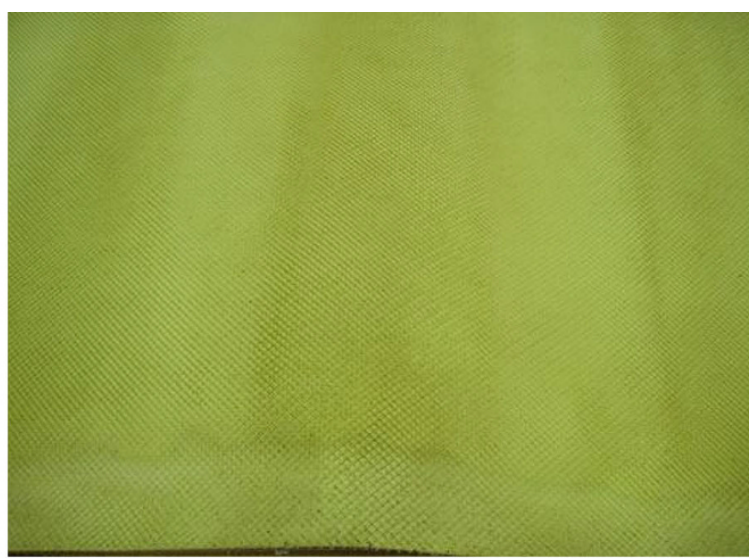

End Element

Fig. 8 Photograph membrane elements used in baseline study—second trial—showing foulant deposits
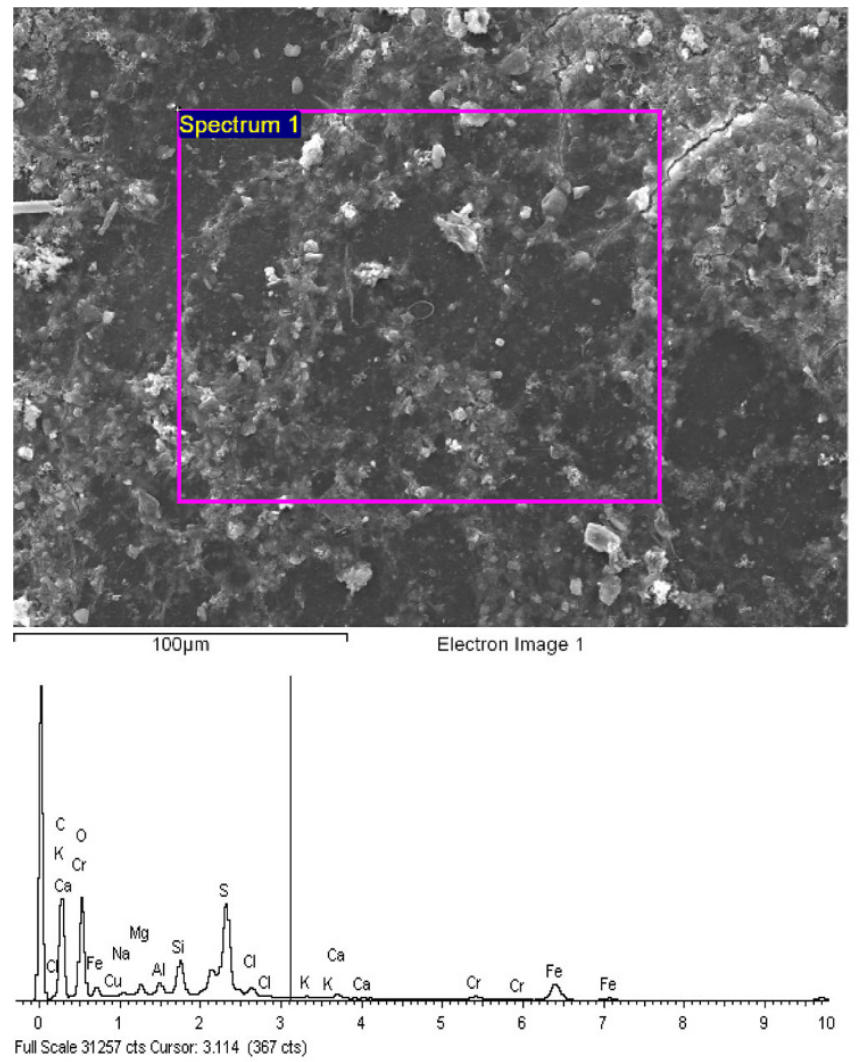

Lead Element
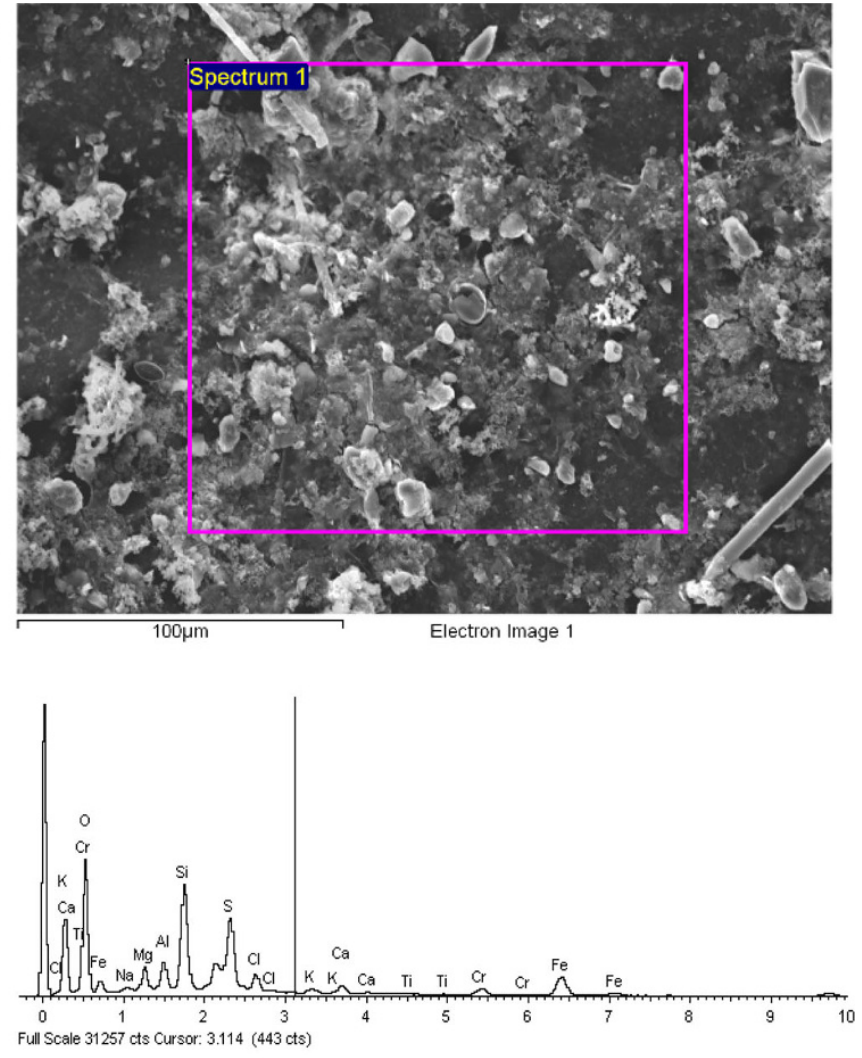

End Element

Fig. 9 SEM image and corresponding EDX spectrum of membrane elements used in baseline study—second trial—showing foulant deposits

surface despite chemical cleaning. This finding as well as the failure of chemical cleaning to restore performance indicates that the membrane fouling is irreversible in nature. The results further confirm the feasibility of SWRO membrane operation using Gulf seawater as feed at a recovery of $30 \%$ without using antiscalant.
Membranes removed for autopsy in offline salt cleaning were operated for a total of 106 days. During the initial 42 days, the feed $\mathrm{pH}$ was 7 , which did not result in significant fouling. Hence, this was increased to 7.25 for another 12 days, and then to a $\mathrm{pH}$ of 7.5. Operation at this $\mathrm{pH}$ continued for 16 days, which did not cause any 


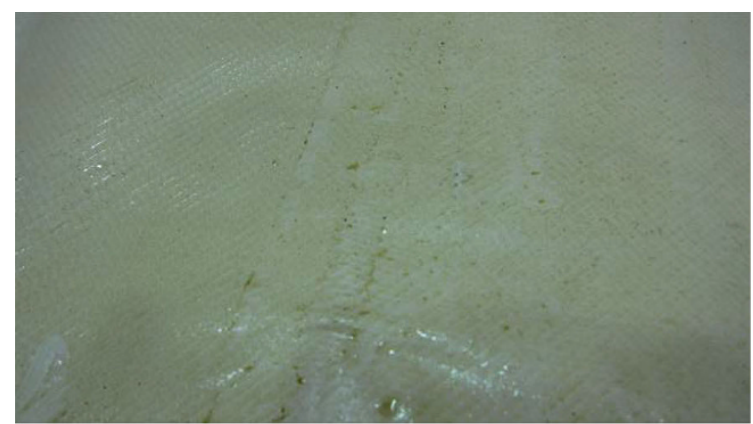

Lead Element

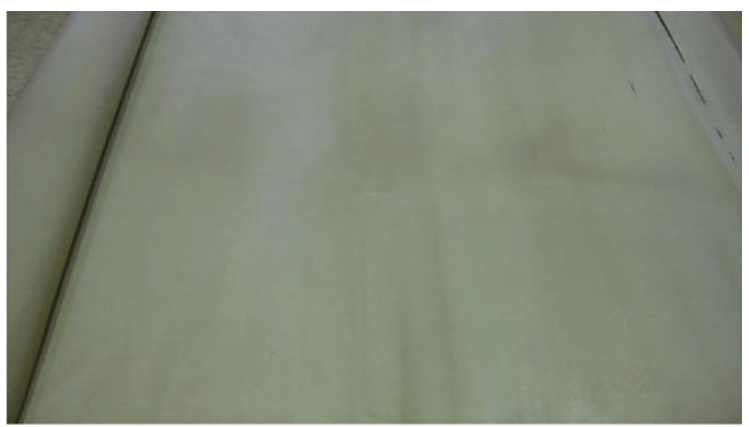

End Element

Fig. 10 Photograph membrane elements used in baseline study — third trial—immediately after chemical cleaning showing foulant deposits
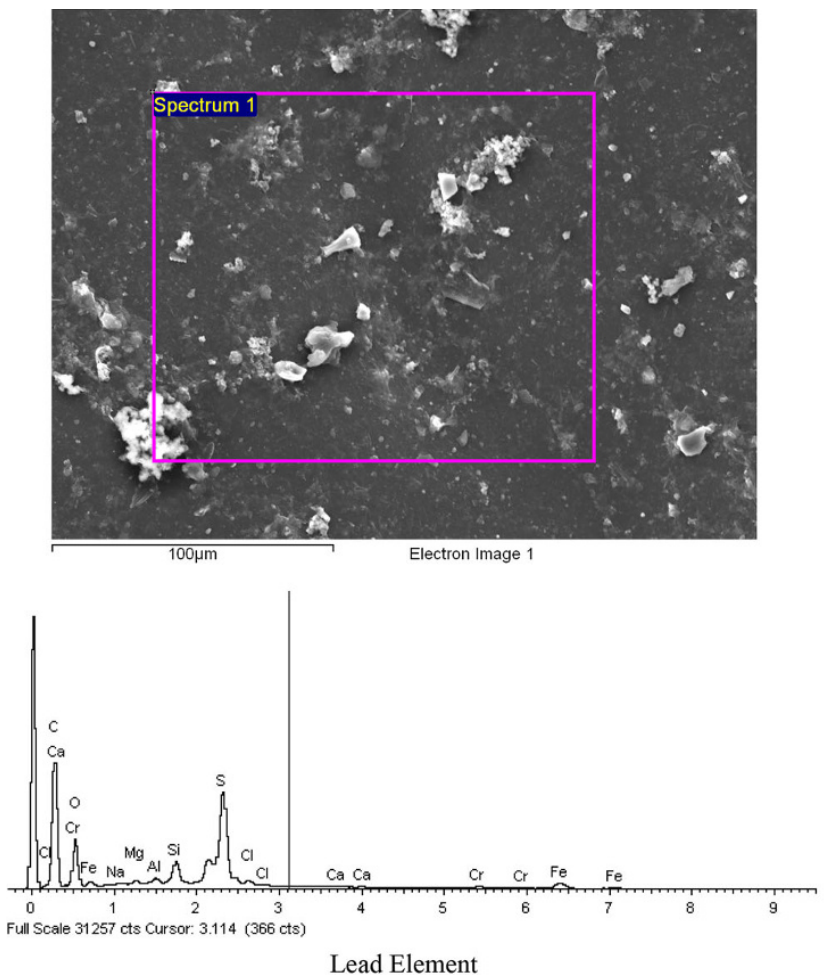
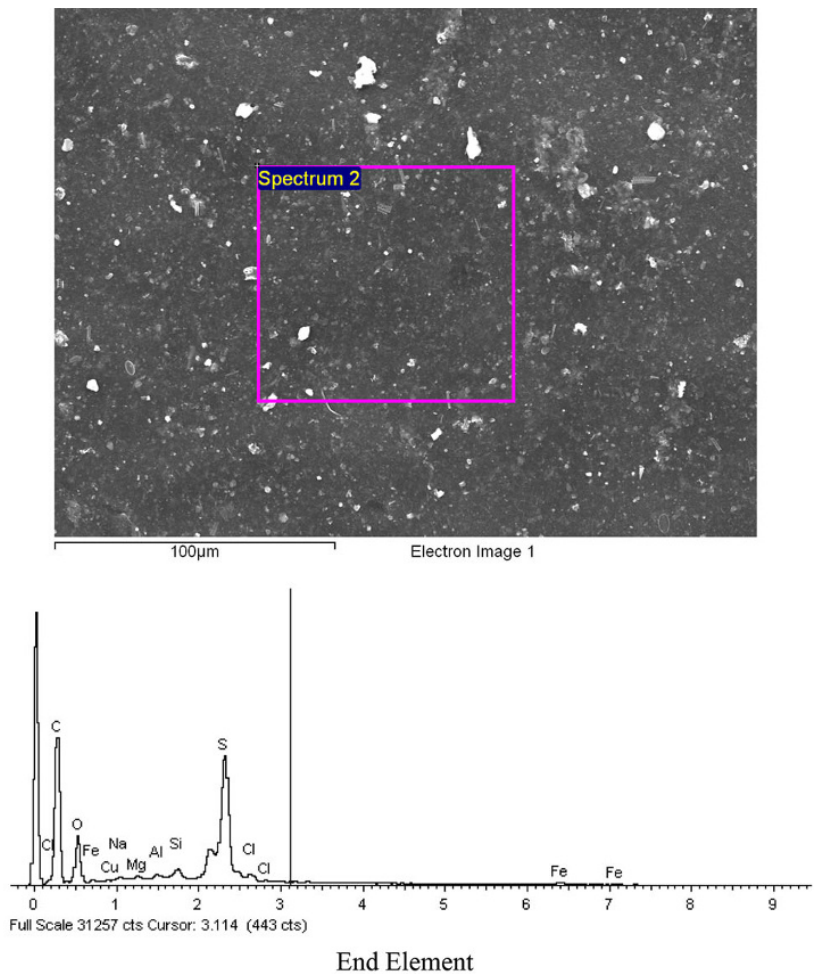

Fig. 11 SEM image and corresponding EDX spectrum of membrane elements used in baseline study—third trial—immediately after chemical cleaning showing very little foulant deposits

significant decline in performance either. As a result, the feed $\mathrm{pH}$ was increased to 7.8 (for 26 days), and finally without adding acid. It was found that after increasing the feed $\mathrm{pH}$ to 7.8 , there was a significant decline in performance. Hence, a total of four salt cleanings were carried out, which, however, failed to recover the loss in performance. Autopsy, which was performed 1 day after the last salt cleaning, showed that both lead and end elements were covered with brown deposits similar to those found during the baseline study (Fig. 12). However, the amount of deposits in the lead element was comparatively greater than that found during all the three trials of baseline studies. Also, the composition of foulant was also similar to that found during baseline studies, with a higher concentration of corrosion products such as iron and chromium (Table 2; Fig. 13). The presence of substantial quantities of iron and chromium indicates the severe corrosion affecting stainless steel pipes. These results demonstrate the failure of offline salt cleaning and associated osmotic backwash to clean efficiently and thus restore membrane performance.

Membranes autopsied during online salt cleaning showed rather high amounts of foulants compared to other modes of operation. This was confirmed by the foulant amount per unit area results as well as by visual inspection and SEM and EDX (Table 3; Figs. 14, 15, 16, $17,18,19)$, indicating faster fouling rates on membranes 


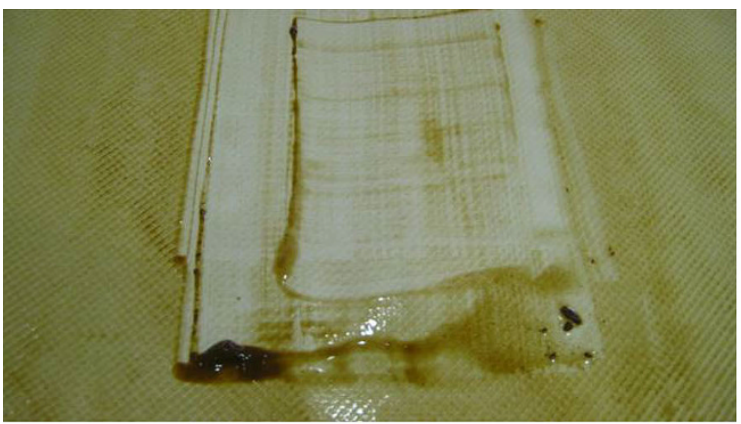

Lead Element

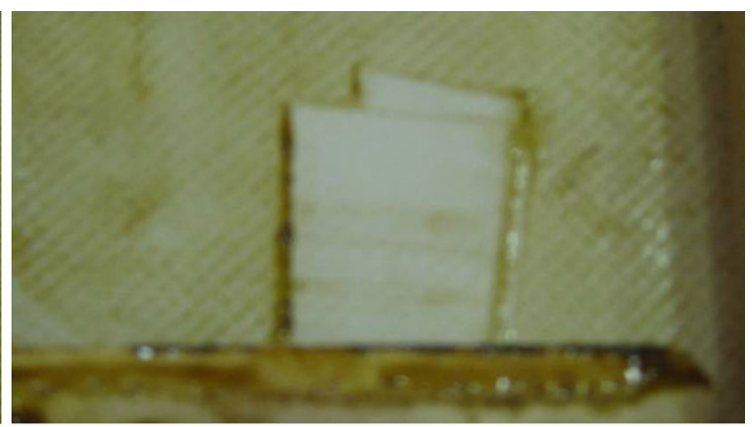

End Element

Fig. 12 Photograph membrane elements subjected to offline salt cleaning showing foulant deposits and scraped area

Table 2 Analyses of foulant deposits on the autopsied membranes used in offline salt cleaning

\begin{tabular}{lll}
\hline Membrane element & Lead element & End element \\
\hline Foulant $\left(\mathrm{mg} / \mathrm{cm}^{2}\right)$ & 0.092 & 0.110 \\
Primary organic matter $(\%)$ & 43.60 & 39.7 \\
$\mathrm{Na}(\%)$ & $\mathrm{ND}$ & $\mathrm{ND}$ \\
$\mathrm{Mg}(\%)$ & 3.70 & 4.5 \\
$\mathrm{Al}(\%)$ & 3.13 & 1.0 \\
$\mathrm{Si}(\%)$ & 13.14 & 15.0 \\
$\mathrm{~S}(\%)$ & 1.19 & 1.1 \\
$\mathrm{Cl}(\%)$ & 1.83 & 1.5 \\
$\mathrm{~K}(\%)$ & 1.38 & 1.6 \\
$\mathrm{Ca}(\%)$ & 3.03 & 6.4 \\
$\mathrm{Cr}(\%)$ & 2.89 & 2.9 \\
$\mathrm{Fe}(\%)$ & 23.57 & 23.7 \\
\hline
\end{tabular}

$N A$ not analyzed, $N D$ not detected

during online salt cleaning. The amount of foulants on the lead and end elements used in the third trial (which were operated under controlled pressure for 36 days) was 0.53 and $0.175 \mathrm{mg} / \mathrm{cm}^{2}$, respectively. This may be compared to the amount of foulants of only 0.059 and $0.004 \mathrm{mg} /$ $\mathrm{cm}^{2}$, respectively, in the lead and elements used in the second trial of the baseline study and operated for 41 days. Exceptions to this were the membranes used in the second trial where the value was comparable to that found in the baseline study. This was probably due to the comparatively shorter operation period of 19 days causing a lower fouling rate on the membrane. The results from this phase reveal that online salt cleaning somehow increased the foulant content on the membrane surface resulting in a faster decline of membrane performance. The increased amount of foulant on the membranes, compared to offline salt cleaning, could also have been due to the absence of high feed cross-flow velocity, which could have helped to flush out some of the foulants from the membrane surface.

\section{Biofilm bacteria}

Biofilm bacteria analyses of autopsied membranes were carried out on two different sets of membranes, each time on both lead and end elements. The first analysis was performed on membranes removed after online salt cleaning (third trial). The second analyses were carried out on two membrane elements following the offline salt cleaning study.

Density of bacteria in feed side element was $1.14 \times 10^{4}$ $\mathrm{CFU} / \mathrm{cm}^{2}$ while density of brine side element was $7.34 \times 10^{5} \mathrm{CFU} / \mathrm{cm}^{2}$, where online salt cleaning was performed. Biofilm was loosely attached and easily scraped off from either element. The second analysis, where offline salt cleaning was performed, revealed similar biofilm densities in both feed and brine side elements with a density of $4.70 \times 10^{4}$ and $6.25 \times 10^{4} \mathrm{CFU} / \mathrm{cm}^{2}$, respectively. These densities are too low to indicate membrane biofouling.

From those membranes subjected to online salt cleaning, eight bacterial isolates were obtained from end element: three isolates represented $67 \%$ of the total isolate count, two isolates were obtained from the lead element with one predominant isolates constituting $83 \%$ of the count. From the membranes autopsied following offline salt cleaning, six bacterial isolates were obtained from the end element with a single predominant isolate accounting for over $50 \%$ of the total count of the six isolates. Four isolates were obtained from the feed side element with one forming $>60 \%$ of their total count. Normally, one or two biofilm bacteria predominate (Saeed 2003).

Salt and $\mathrm{pH}$ tolerance tests were carried out on the ten isolates from the membranes autopsied following the baseline study. It was found that nine of the ten isolates tolerated $48 \mathrm{~h}$ exposure to $20 \%$ salt concentration (about 5 times higher than that of Gulf seawater), while seven out of the ten isolates tolerated $48 \mathrm{~h}$ exposure to $30 \%$ salt concentration (about 8 times higher than that of Gulf seawater). The dominant isolates on the brine side tolerated 

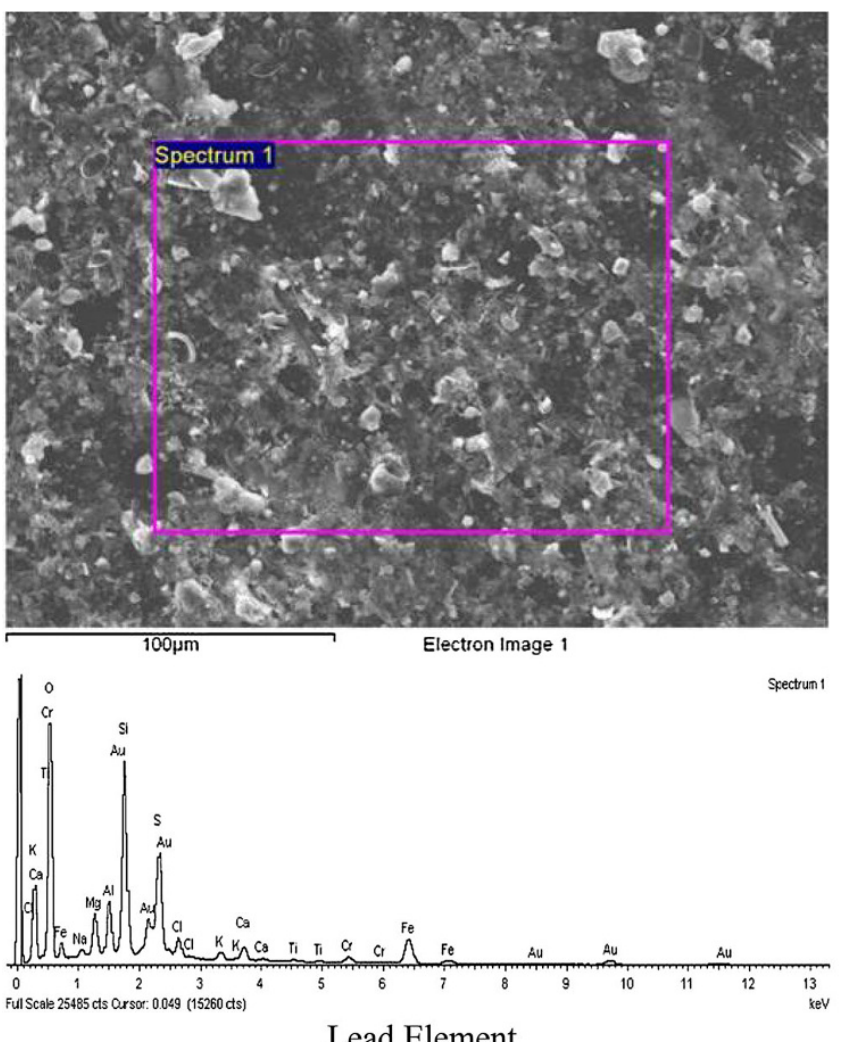
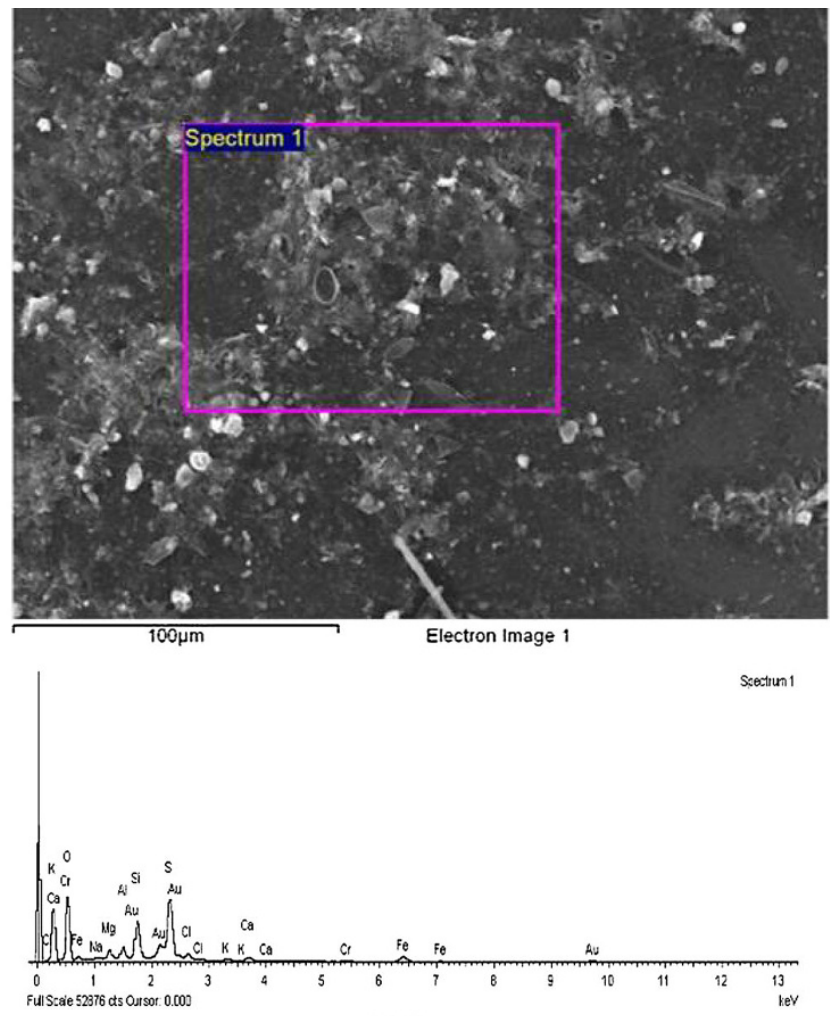

End Element

Fig. 13 SEM image and corresponding EDX spectrum of membrane elements subjected to offline salt cleaning showing foulant deposits

Table 3 Analyses of foulant deposits on the autopsied membranes used in online salt cleaning

\begin{tabular}{|c|c|c|c|c|c|c|}
\hline \multirow{2}{*}{$\begin{array}{l}\text { Membrane } \\
\text { element }\end{array}$} & \multicolumn{2}{|l|}{ 1st trial } & \multicolumn{2}{|l|}{ 2nd trial } & \multicolumn{2}{|l|}{ 3rd trial } \\
\hline & $\begin{array}{l}\text { Lead } \\
\text { element }\end{array}$ & $\begin{array}{l}\text { End } \\
\text { element }\end{array}$ & $\begin{array}{l}\text { Lead } \\
\text { element }\end{array}$ & $\begin{array}{l}\text { End } \\
\text { element }\end{array}$ & $\begin{array}{l}\text { Lead } \\
\text { element }\end{array}$ & $\begin{array}{l}\text { End } \\
\text { element }\end{array}$ \\
\hline $\begin{array}{l}\text { Foulant } \\
\qquad\left(\mathrm{mg} / \mathrm{cm}^{2}\right)\end{array}$ & 0.395 & 0.251 & 0.045 & 0.004 & 0.530 & 0.175 \\
\hline $\begin{array}{l}\text { Primary } \\
\text { organic } \\
\text { matter } \\
(\%)\end{array}$ & 36.4 & 36.3 & 46.4 & 43.9 & 43.8 & 44.7 \\
\hline $\mathrm{Na}(\%)$ & 1.9 & ND & ND & ND & ND & 1.7 \\
\hline $\operatorname{Mg}(\%)$ & 2.7 & 2.9 & 2.7 & 2.8 & 3.2 & 2.8 \\
\hline $\mathrm{Al}(\%)$ & 0.4 & 1.3 & 0.3 & ND & 0.2 & 0.3 \\
\hline $\mathrm{Si}(\%)$ & 3.9 & 6.0 & 1.0 & 0.7 & 0.4 & 0.8 \\
\hline $\mathrm{S}(\%)$ & 0.9 & 1.1 & 1.1 & 0.7 & 0.4 & 0.5 \\
\hline $\mathrm{Cl}(\%)$ & 2.4 & $\mathrm{ND}$ & 1.3 & ND & ND & 2.2 \\
\hline K (\%) & 0.4 & 0.3 & 0.1 & ND & ND & 0.1 \\
\hline $\mathrm{Ca}(\%)$ & 22 & 28 & 3.9 & 3.5 & 3.5 & 2.8 \\
\hline $\mathrm{Cr}(\%)$ & 4 & 11.9 & 6.4 & 6.8 & 7.3 & 6.6 \\
\hline $\mathrm{Fe}(\%)$ & 22.5 & 18.7 & 34.7 & 38.8 & 38.9 & 35.2 \\
\hline
\end{tabular}

$N D$ not detected higher salt concentrations than those on the feed side element. However, the dominant isolates on both brine and feed side elements easily tolerated $48 \mathrm{~h}$ exposure to $20 \%$ salt concentration. The conclusion is that exposing membranes to a concentrated salt solution was not effective in deactivating biofilm bacteria.

$\mathrm{pH}$ tolerance was tested in a marine broth, where $\mathrm{pH}$ was adjusted to values between 4.0 and 11.0. All isolates tolerated 5 days exposure to $\mathrm{pH}$ of $5-9$, and a few of them could grow in a $\mathrm{pH}$ range of 4.0-11.0. Therefore, $\mathrm{pH}$ change within the range of 5-9 will not affect the survival of biofilm bacteria. Citric acid, which was ammoniated to a $\mathrm{pH}$ of 4.0, was found to kill $100 \%$ of all bacterial isolates, and is therefore an effective cleaning agent against biofilm bacteria.

Effect of $\mathrm{pH}$ on fouling rate

During the initial part of the study, the only chemical dosed was sulfuric acid, which was used to maintain the feed $\mathrm{pH}$ to about 6.7 so as to prevent scaling. However, during the course of the baseline study (first trial), it was found that all measures taken to accelerate membrane fouling (as evident 


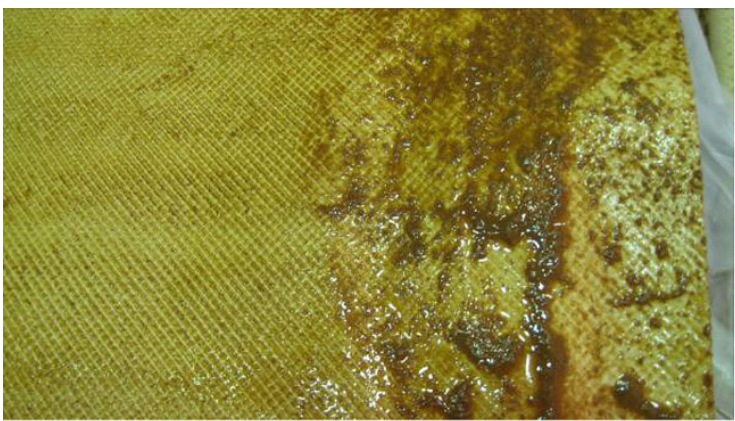

Lead Element

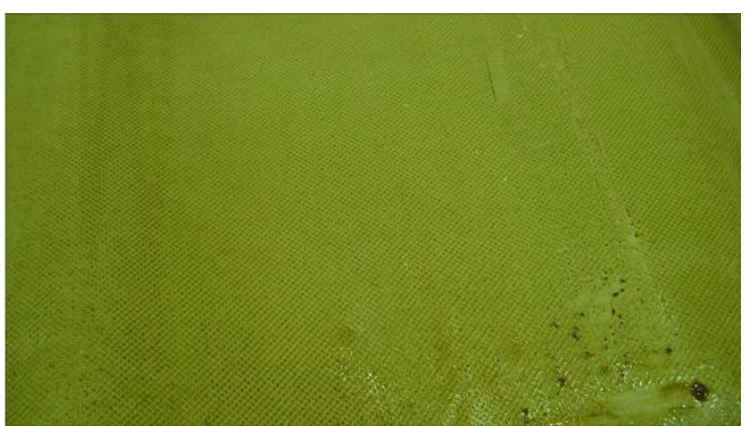

End Element

Fig. 14 Photograph membrane elements subjected to online salt cleaning with uncontrolled feed pressure—first trial—showing foulant deposits
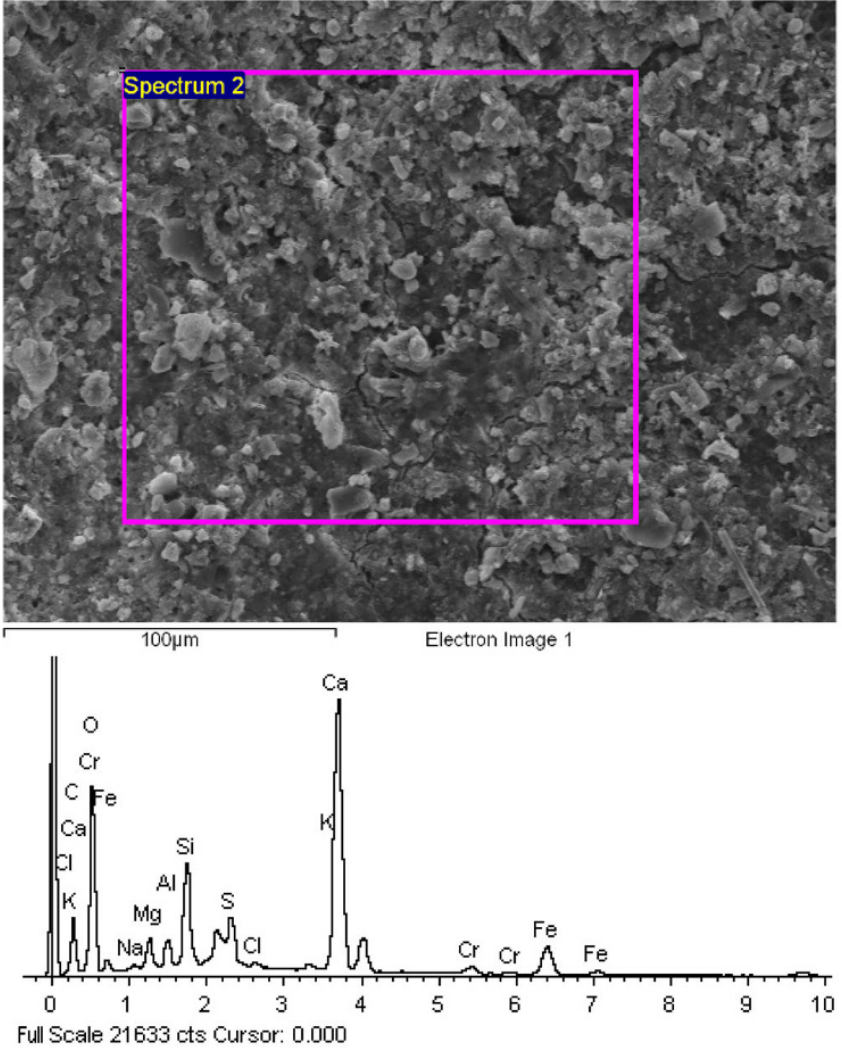

Lead Element
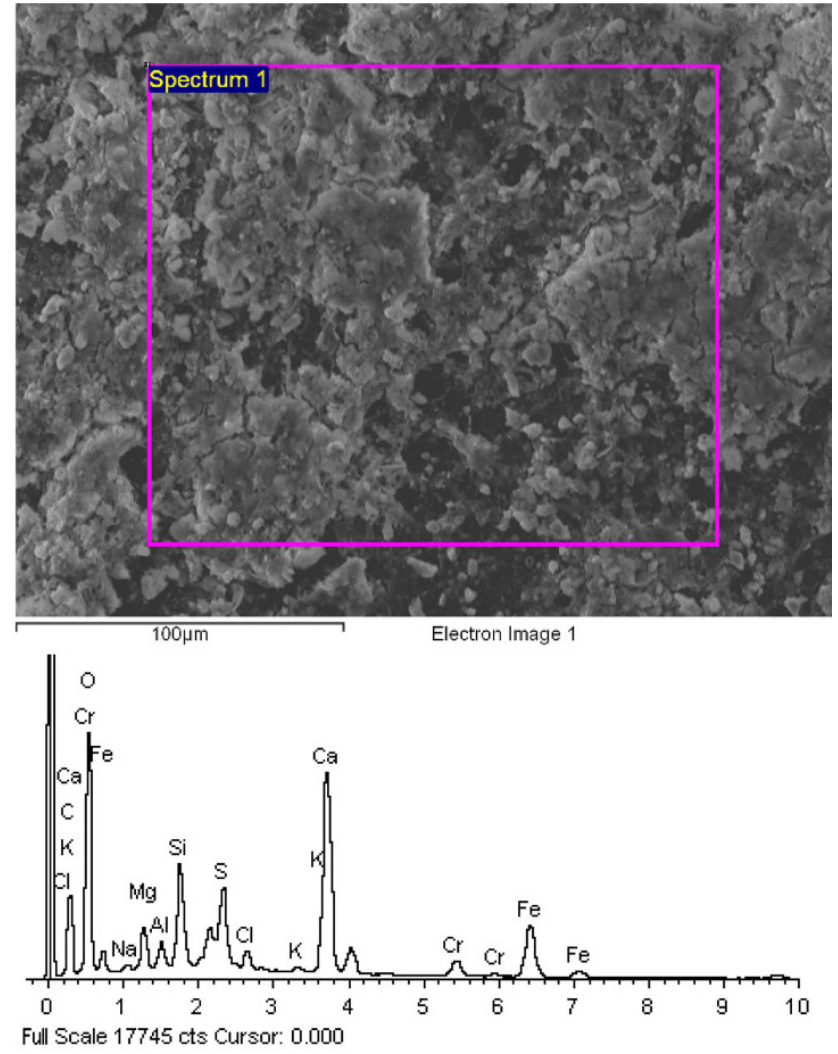

End Element

Fig. 15 SEM image and corresponding EDX spectrum of membrane elements subjected to online salt cleaning with uncontrolled feed pressure-first trial-showing foulant deposits

by performance decline) had failed. These measures included increasing the membrane flux, by-passing the sand filter as well as increasing the recovery. Another approach involved increasing the feed $\mathrm{pH}$ to a higher value to accelerate the decline in the membrane performance by inducing scaling. This was done gradually by reducing the acid dosing rate which resulted in an increase of feed $\mathrm{pH}$ from 6.7 to the natural $\mathrm{pH}$ of seawater of about 8 . However, there was no significant impact, as was evident from the performance decline results as well as autopsy studies. The last two baseline studies (second and third trial) were completed without dosing acid or any chemicals, especially, the third trial, which was extended up to 70 days. This result indicates that even at a recovery of $30 \%$, SWRO membranes can operate smoothly on Gulf seawater feed without the addition of scale control chemicals. 


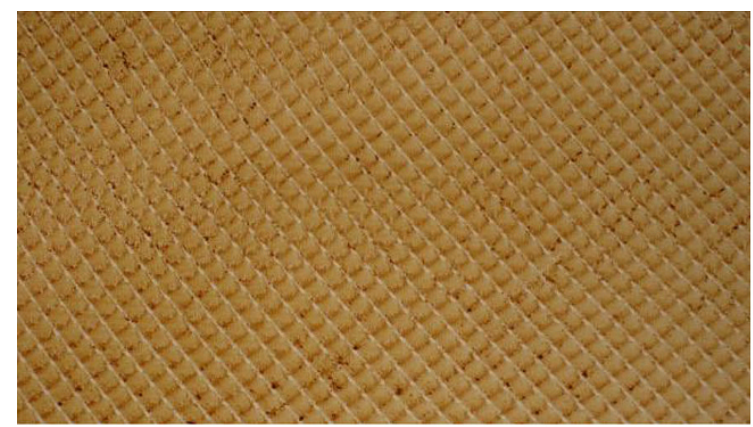

Lead Element

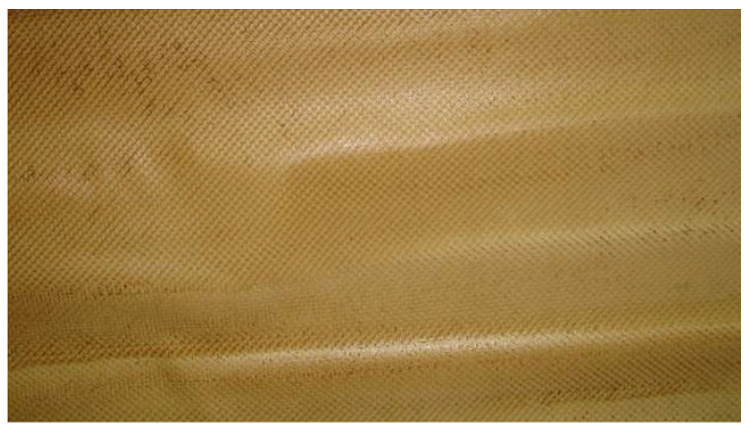

End Element

Fig. 16 Photograph of membrane elements subjected to online salt cleaning with controlled feed pressure—second trial—showing foulant deposits
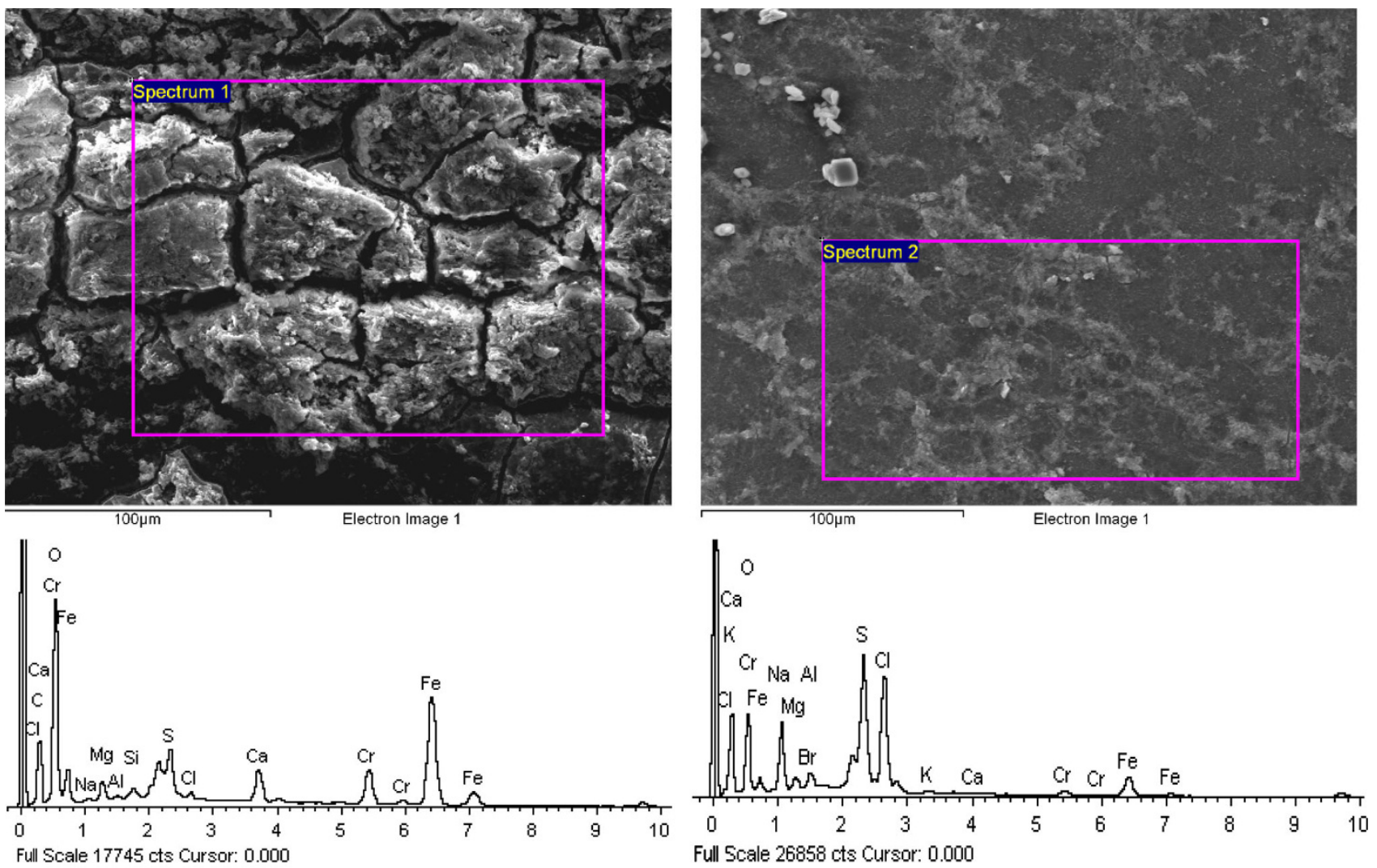

Lead Element

End Element

Fig. 17 SEM image and corresponding EDX spectrum of membrane elements subjected to online salt cleaning with controlled feed pressuresecond trial一showing foulant deposits

Osmotic backwash flow rate during salt dosing

During offline salt cleaning, the use of a high salt concentration was expected to result in osmotic backwash from permeate side to feed side of membrane due to the large osmotic pressure difference reflecting the different salt concentrations on feed and permeate sides of the membrane. As the salt concentration in the permeate is almost constant and very small, the backwash flow rate of permeate water to the feed side is proportional to the salt concentration in the feed side. However, offline salt cleaning was found to be ineffective in restoring membrane performance, indicating that the osmotic backwash did not sufficiently detach foulant deposited on the membrane surface. Even online salt cleaning, which was performed on daily basis, proved ineffective despite using a very high concentration of salt ( $\approx 25 \%$ ). For this reason, during the course of online salt cleaning, the reverse flow from the 


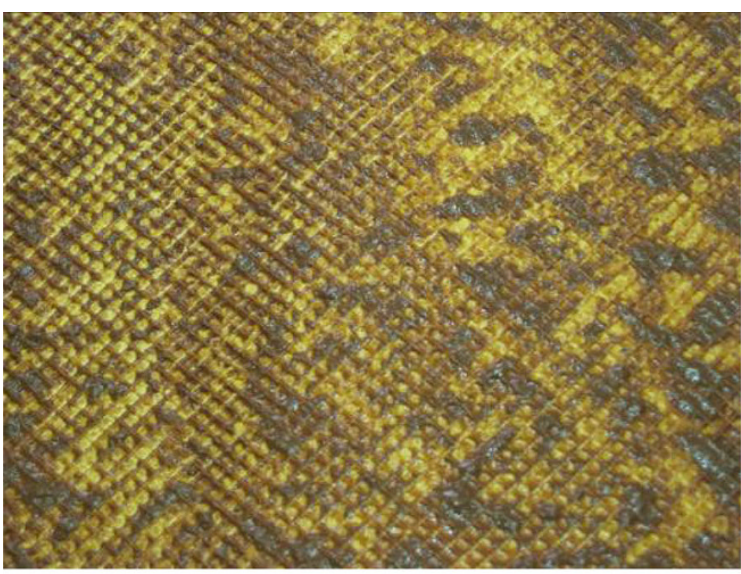

Lead Element

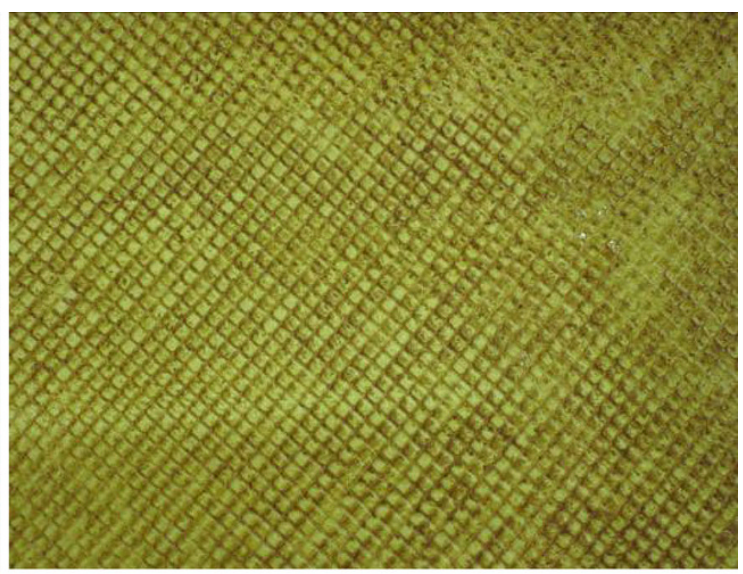

End Element

Fig. 18 Photograph of membrane elements subjected to online salt cleaning with controlled feed pressure—third trial—showing foulant deposits
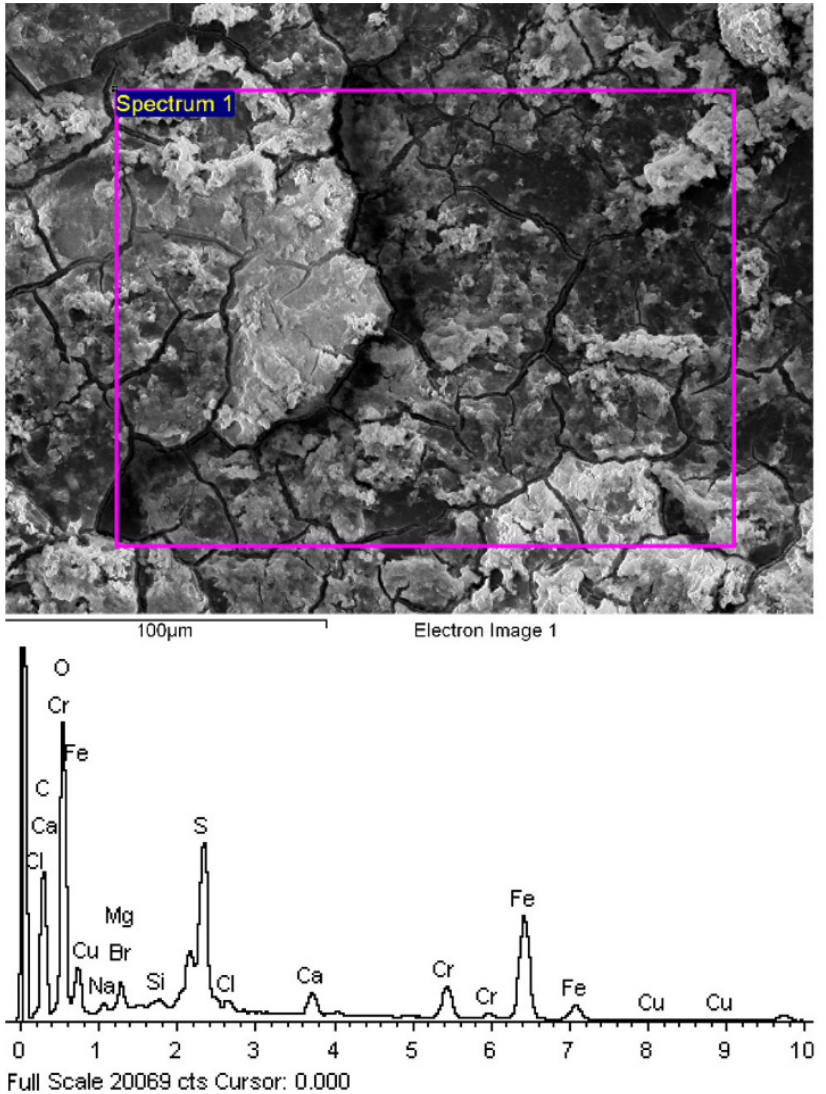

Lead Element
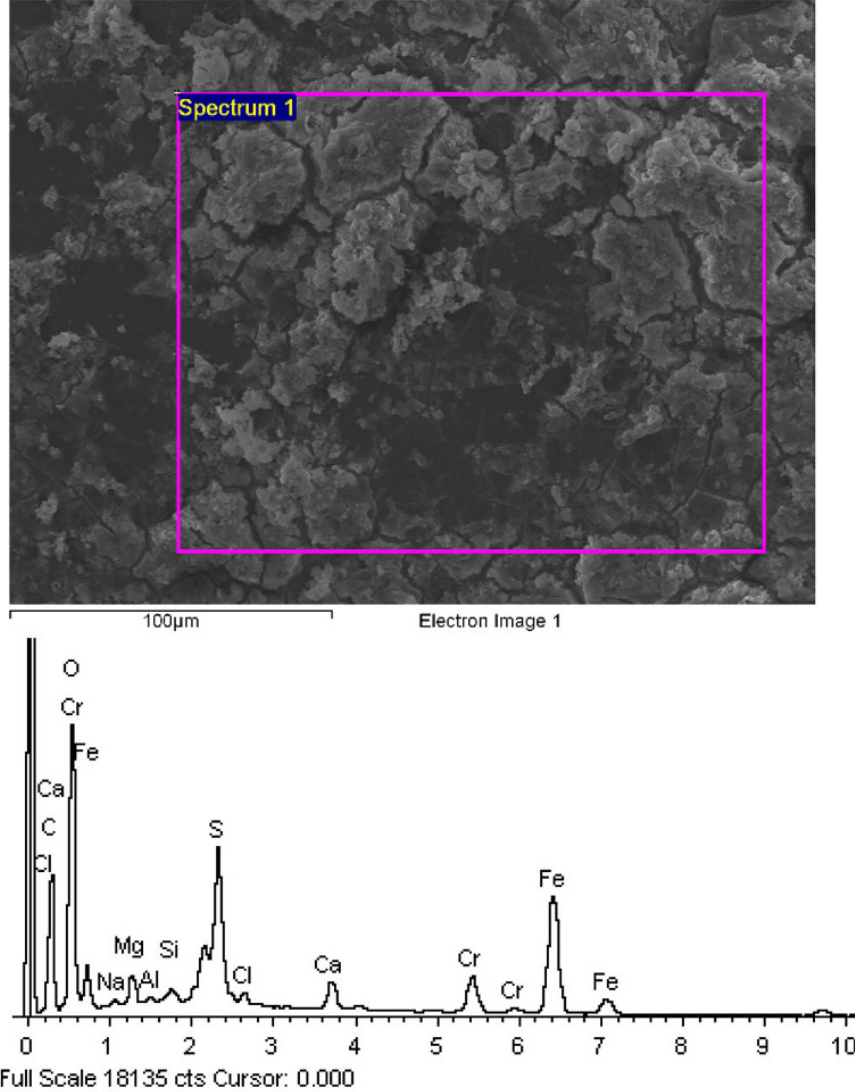

End Element

Fig. 19 SEM image and corresponding EDX spectrum of membrane elements subjected to online salt cleaning with controlled feed pressurethird trial—showing foulant deposits

permeate tank back to the membrane was monitored by installing a flow meter on the permeate line. It was observed that there was a reverse flow from the permeate tank, which was directly proportional to the concentration of salt solution dosed, as is shown in Fig. 20. This figure shows the average osmotic backwash flux attained by dosing different concentrations of salt solution. The maximum backwash flux obtained was only about $<11 \mathrm{LMH}$, which is much less than the membranes flux of $23 \mathrm{LMH}$ under normal SWRO operating conditions. This could probably explain why offline salt cleaning and online salt dosing failed to produce sufficient osmotic backwash flux. 


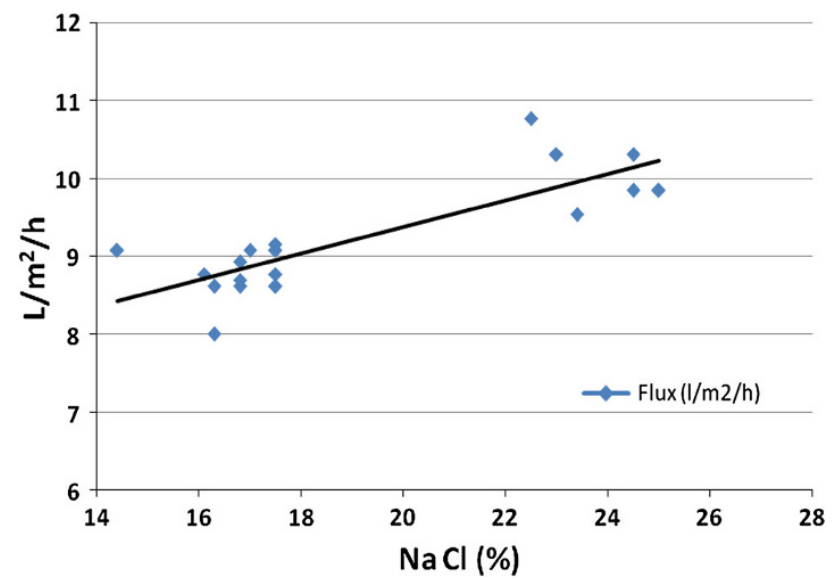

Fig. 20 Osmotic backwash flux $\left(1 / \mathrm{m}^{2} / \mathrm{h}\right)$ during online dosing of super saline solution

It is the osmotic backwash flux intensity, which is the main parameter that helps in dislodging the foulant deposited on the membrane surface. This low osmotic backwash flux was obtained despite a large osmotic pressure difference of about $>100$ bar, available as a driving force to induce backwash flow. A concentration of $25 \% \mathrm{NaCl}$ results in an osmotic pressure equivalent to about 195 bar. After deducting the feed pressure of about 70 bar, a net osmotic pressure of about 125 bar is theoretically available to induce a high osmotic backwash flow, but this did not happen in practice. The tight configuration of spiral wound membrane as well as the inherent properties of SWRO membranes could have prevented the smooth osmotic backwash flow from the permeate side to the feed side of the membrane (Qin et al. 2009; Merdaw et al. 2010). Moreover, the osmotic backwash flow is diffusive in nature rather than convective flow. The latter can help to dislodge adhering foulants on membrane surface as well as pores. The applied pressure in the feed channel reportedly reduces the osmotic backwash driving force even where feed pressures range from 5 to 10 bar. This is attributed to a decrease in diffusivity, resulting from the membrane's slight compression under the applied pressure (Sagiv and Semiat 2010a, b). Hence, in the present case, the applied feed pressure in the range of 60-70 bar is expected to significantly reduce osmotic backwash flux, as is quite evident from the obtained results. This could explain the failure of osmotic backwash to restore SWRO membrane performance.

\section{Conclusions}

The study found that offline and online salt cleaning using very high concentrations of sodium chloride solution was not effective in either controlling fouling or significantly removing foulants from the membrane surface. On the contrary, online salt cleaning actually resulted in a higher fouling rate on membranes. Although the driving force for the osmotic backwash was present during online salt dosing, the generated back flow proved insufficient to detach foulants from membrane surfaces. During the study period the average membrane flux remained between 19 and 23 LMH; whereas, the average back flow flux generated by a high salt concentration solution was only $11 \mathrm{LMH}$ which was not enough to remove adhering foulants. Moreover, the membrane configuration as well as the inherent properties of SWRO membrane apparently places certain constraints on the osmotic backwash process, thus rendering it ineffective in tackling membrane fouling. The study found that the distinctive biofouling of membranes was absent despite not using any disinfection. However, it was shown that the biofilm bacteria are tolerant to both high salt concentrations with $\mathrm{pH}$ in the range of 7-8 while some bacterial isolates are tolerant to a wide range of $\mathrm{pH}(4.0-11.0)$.

Although offline and online salt cleaning using high salt concentrations did not offer any positive results in terms of preventing/controlling fouling, the overall findings from indicated that SWRO membranes can operate on Gulf seawater at a recovery of $30 \%$, without using chemicals such as coagulant, disinfectant and antiscalant for an acceptable period of time and without performing membrane cleaning. This is especially feasible, if a media filter is used during the pretreatment and the membranes are operated at normal flux and recovery ratios. Consequently, further study is being undertaken to operate SWRO membrane systems with few if any chemicals, which should ultimately lead to an environmentally friendly SWRO operational method.

Acknowledgments Mr. Mohamed Al-Anazi followed up the dayto-day activities of the project. Mr. Mohamed Al-Ajlan assisted in microbial studies. Mr. Prasanna Kurup and Mr. Gaheishi Al-Dowis supported in chemical analyses and Mr. Ali Al-Yami supported in membrane autopsy. Finally, Mr. Anton Schulz (SWCC Training Centre) efforts are acknowledged for language editing.

Open Access This article is distributed under the terms of the Creative Commons Attribution License which permits any use, distribution, and reproduction in any medium, provided the original author(s) and the source are credited.

\section{References}

4516-85 D (1989) Standard practice for standardizing reverse osmosis performance data. The annual book of ASTM standard. ASTM

Avraham N, Dosoretz C, Semiat R (2006) Osmotic backwash process in RO membranes. Desalination 199:387-389

Lee S, Elimelech M (2007) Salt cleaning of organic-fouled reverse osmosis membranes. Water Res 41:1134-1142 
Liberman B, Liberman I (2005) Replacing membrane CIP by Direct Osmosis cleaning. Int Desalin Water Reuse Q 15(2):28

Liberman B, Rooij F, Faigon M (2007) Practical implementation of RO membranes backwash technology. In: Proceedings of the IDA world congress on desalination and water reuse, Maspalomas, Gran Canaria, Spain, 21-26 Oct. 2007. International Desalination Association

Merdaw AA, Sharif AO, Derwish GAW (2010) Water permeability in polymeric membranes, Part I. Desalination 260(1-3):180-192

Qin J-J, Liberman B, Kekre KA (2009) Direct osmosis for reverse osmosis fouling control: principles, applications and recent developments. Open Chem Eng J 3:8-16

Qin J-J, Oo MH, Kekre KA, Liberman B (2010) Development of novel backwash cleaning technique for reverse osmosis in reclamation of secondary effluent. J Membr Sci 346(1):8-14

Ramon G, Agnon Y, Dosoretz C (2010) Dynamics of an osmotic backwash cycle. J Membr Sci 364(1-2):157-166

Saeed MO (2000) Biofouling in a seawater reverse osmosis plant on the Red Sea coast of Saudi Arabia. Desalination 128:177-190
Saeed MO (2002) Effect of the intake bay design on feed water quality for the Jubail desalination and power plants. In: Proceedings of the 6th Saudi engineering conference, King Fahd University of Petroleum and Minerals, Dhahran, Saudi Arabia, Dec 14-17, 2002, pp 3-16

Saeed MO (2003) A bacterium associated with fouling of a chlorinated seawater RO membrane. In: Proceedings of international conference on desalination and water reuse, San Diego, USA

Sagiv A, Semiat R (2005) Backwash of RO spiral wound membranes. Desalination 179:1-9

Sagiv A, Semiat R (2010a) Modeling of backwash cleaning methods for RO membranes. Desalination 261(3):338-346

Sagiv A, Semiat R (2010b) Parameters affecting backwash variables of RO membranes. Desalination 261(3):347-353

Sagiv A, Avraham N, Dosoretz CG, Semiat R (2008) Osmotic backwash mechanism of reverse osmosis membranes. J Membr Sci 322(1):225-233 